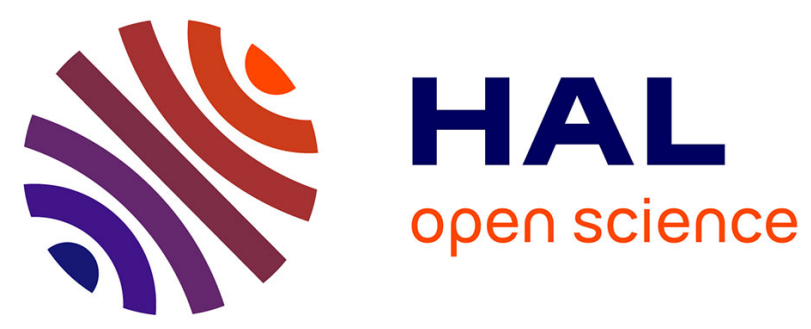

\title{
Evolution of the northern Turkana Depression (East African Rift System, Kenya) during the Cenozoic rifting: New insights from the Ekitale Basin (28-25.5 Ma)
} Théa Ragon, Alexis Nutz, Mathieu Schuster, Jean-François Ghienne, Gilles Ruffet, Jean-Loup Rubino

\section{To cite this version:}

Théa Ragon, Alexis Nutz, Mathieu Schuster, Jean-François Ghienne, Gilles Ruffet, et al.. Evolution of the northern Turkana Depression (East African Rift System, Kenya) during the Cenozoic rifting: New insights from the Ekitale Basin (28-25.5 Ma). Geological Journal, 2019, 54 (6), pp.3468-3488. 10.1002/gj.3339 . insu-01903272

\section{HAL Id: insu-01903272 \\ https://hal-insu.archives-ouvertes.fr/insu-01903272}

Submitted on 13 Nov 2018

HAL is a multi-disciplinary open access archive for the deposit and dissemination of scientific research documents, whether they are published or not. The documents may come from teaching and research institutions in France or abroad, or from public or private research centers.
L'archive ouverte pluridisciplinaire HAL, est destinée au dépôt et à la diffusion de documents scientifiques de niveau recherche, publiés ou non, émanant des établissements d'enseignement et de recherche français ou étrangers, des laboratoires publics ou privés. 


\title{
Evolution of the northern Turkana Depression (East African Rift System, Kenya) during the Cenozoic rifting: New insights from the Ekitale Basin (28-25.5 Ma)
}

\author{
T. Ragon ${ }^{1,2}$, A. Nutz ${ }^{1,3}$, M. Schuster ${ }^{1}$, J-F. Ghienne ${ }^{1}$, G. Ruffet ${ }^{4}$ and J-L. Rubino ${ }^{5}$ \\ ${ }^{1}$ Université de Strasbourg, CNRS, Institut de Physique du Globe de Strasbourg, UMR 7516, 67084 Strasbourg, France \\ 2 Université Côte d'Azur, CNRS, Observatoire de la Côte d'Azur, IRD, Géoazur, 06560 Valbonne, France \\ ${ }^{3}$ Department of Geoscience, Aarhus University, 8000 Aarhus C, Denmark \\ ${ }^{4}$ Géosciences Rennes, CNRS (CNRS/INSU) UMR 6118 and Université de Rennes 1, Géosciences Rennes, F-35042 Rennes Cedex, \\ France \\ ${ }^{5}$ Total SA, CSTJF, 64018 Pau Cedex, France
}

\section{ABSTRACT}

Two sedimentary basins are identified in the Turkana Depression (East African Rift System, Kenya). One of them, the Ekitale Basin, is presented in detail. Located on the western rift shoulder of the northern Turkana Depression, the preserved portion of the Ekitale Basin is 3-5-km-wide and bordered by $\mathrm{N}^{\circ} 0^{\circ}-50^{\circ}$ normal faults. These normal faults were inherited from the reactivation of preexisting basement structures. The Ekitale Basin is filled by the $75 \mathrm{~m}$ thick Topernawi Formation. The lower portion of the formation provides evidence that the basin was occupied by a lake, bordered by alluvial fans, and into which river-derived turbiditic complexes were deposited. The upper portion is comprised of pyroclastic deposits, originating from volcanic activity, and interbedded with fluvial deposits emplaced during periods of volcanic quiescence. The Ekitale Basin opened just after $28 \mathrm{Ma}$ and was abandoned prior to $25 \mathrm{Ma}$, placing it after the deposition of the Oligocene Traps (ca. 33.9-27 $\mathrm{Ma}$ ) and prior to the rift climax (after $14 \mathrm{Ma}$ ). This syn-rift basin largely impacts our understanding of the Cenozoic rift evolution in the Turkana Depression. It helps to identify, for the first time, the first pulse of extension of the Cenozoic rifting, revealing a two-step rifting scenario for the northern Turkana Depression. The Ekitale basin, and analogous syn-rift basins, is believed to have developed from the reactivation of pre-existing structures during a period of extension marked by low differential stress and a low amount of extension.

KEYWORDS: EARS, fluvio-lacustrine, continental rift, Oligocene, Topernawi Formation, turbidites, fan delta, volcaniclastics 


\section{INTRODUCTION}

The successive steps in the evolution of a continental rift has been conceptualized within several analogical and conceptual models (e.g., Cowie, 1998; Gupta et al., 1998; Cowie et al., 2000; Gawthorpe and Leeder, 2000; Fossen and Rotevatn, 2016; Whipp et al., 2016). In these models, the early phase of continental rifting is characterized by the development of kilometer-scale, juxtaposed and isolated depocenters bordered by normal faults. These faults are oriented perpendicular to the orientation of the extension. Subsequently, ongoing extension results in the linkage of these kilometer-scale depocenters and the development of larger half-grabens or grabens (tens of kilometers long and wide) bordered by major normal faults oriented in a similar direction (Cartwright et al., 1995; Dawers and Anders, 1995; Gupta et al., 1998; Ackermann et al., 2001; Mansfield and Cartwright, 2001). These two successive phases are summarized in a two-step model of rifting (Prosser et al., 1993) referred to as the initiation stage and the rift climax. However, field-based investigations of such rift evolution are rare, highlighting the need for ground-truth validation of these evolutionary models.

Following the pioneering work of Gregory (1896), the East African Rift System (EARS) has been investigated intensively through a combination of field geology and seismic imagery. The morphologies of half-grabens and grabens as well as the location of transfer and relay zones are now well constrained (e.g., Rosendahl, 1987; Morley et al., 1992; Morley, 1999a; Tiercelin and Lezzar, 2002; Chorowicz, 2005; Macgregor, 2015; Simon et al., 2017). Nevertheless, unresolved issues remain about the past evolution of the EARS. First, the timing of rift initiation is only partially known in several places along both the western and the eastern branches of the EARS. Second, early rift evolution is very poorly documented. Third, the successive evolutionary steps of Cenozoic rifting remain poorly recognized, and their genetic relationships with stress evolution are poorly understood. Finally, although the history of Cenozoic rifting of the EARS is relatively well understood at a continental scale, detailed reconstructions of rifting at the local scale are rare. The latter is particularly true for long-term active areas such as the Turkana Depression where syn-rift basins have only been described for the most recent $5 \mathrm{Ma}$, notably through the investigation of the Plio-Quaternary Omo Group (e.g., Harris et al., 1988; McDougall and Feibel, 1999; Gathogo and Brown, 2006; Tiercelin et al., 2012; Nutz et al., 2017). Older events in this area remain undocumented.

Here, we identify two previously unknown kilometer-scale basins. The Ekitale Basin is infilled by a 75-m-thick sediment accumulation that, in this study, we name the Topernawi Formation. Description of the Ekitale Basin provides a novel vision of regional rift evolution. This study aims to (i) characterize the tectono-sedimentary evolution of the Ekitale Basin; (ii) reveal the timing of its initiation and abandonment; (iii) integrate this basin into the Cenozoic rifting history of the northern Turkana Depression; and (iv) discuss controls on the nature of the successive syn-rift basins in the northern Turkana Depression. Building upon geological mapping, cross-sections and the interpretation of sedimentary infill cropping out along river incisions, we propose a synthetic 
tectono-sedimentary model that illustrates the complete evolution of Cenozoic rifting in the northern Turkana Depression. Our study offers a field-based example of rift initiation and evolution. It also highlights a new type of syn-rift basin that likely develops due to specific stress conditions either during periods of early rifting or decreased relative extension within a phase of larger-scale rifting.

\section{GEOLOGICAL BACKGROUND}

\subsection{Regional structural framework}

The Turkana Depression, part of the EARS (Fig. 1A), corresponds to a 300-km-long and 200-km-wide lowland separating the Main Ethiopian Rift to the north and the northern Kenyan Rift to the south (Dunkelman et al., 1988; Dunkelman et al., 1989; Rosendahl, 1987; Wescott et al., 1993; Morley et al., 1999; Ebinger et al., 2000; Tiercelin et al., 2012a; Brune et al., 2017). The Turkana Depression is composed of several N-S-oriented half-grabens (Figs. 1B,C) that developed during several episodes of extension dating from the Upper Eocene/Lower Oligocene to the present (Morley et al., 1999; Tiercelin and Lezzar, 2002; Vétel and Le Gall, 2006; Macgregor, 2015). The area contains three largescale basement-inherited fault zones, oriented $\mathrm{N} 50^{\circ}$ and $\mathrm{N} 140^{\circ}$ (Fig. 1B) known as the Buluk, Kataboi and N'Doto-Karisia fault zones (BFZ, KFZ and NKFZ, respectively) (Vétel, 2005; Vétel and Le Gall, 2006). They are thought to have either strongly (NKFZ) or likely (for KFZ and BFZ) influenced the nucleation and the distribution of basins in the Turkana Depression throughout Cenozoic rifting (Vétel and Le Gall, 2006).

The Turkana Depression is subdivided into two main parts based on structural characteristics. The southern part of the Turkana Depression-the most well-documented area due to oil exploration (Tiercelin et al. 2012b)-consists of five juxtaposed N-S-oriented half-grabens known as the Naipa, Lokichar, Turkwel, Kerio and South Lake basins (Figs. 1B, C). These five basins form a $>200-\mathrm{km}$-wide rift system (sensu Buck, 1991) characterized by relatively low relief due to the low elevation of the basin shoulders. In this area, Cenozoic rifting is believed to have started ca. $35 \mathrm{Ma}$ in the Lokichar Basin (Morley et al., 1999; Vétel and Le Gall, 2006). During the early Miocene (23-15 Ma), rifting extended farther east with the opening of the Turkwel and Kerio basins (Vétel and Le Gall, 2006). Slightly before $10 \mathrm{Ma}$, the South Lake Basin was likely already open (Morley et al., 1999; Vétel and Le Gall, 2006). 


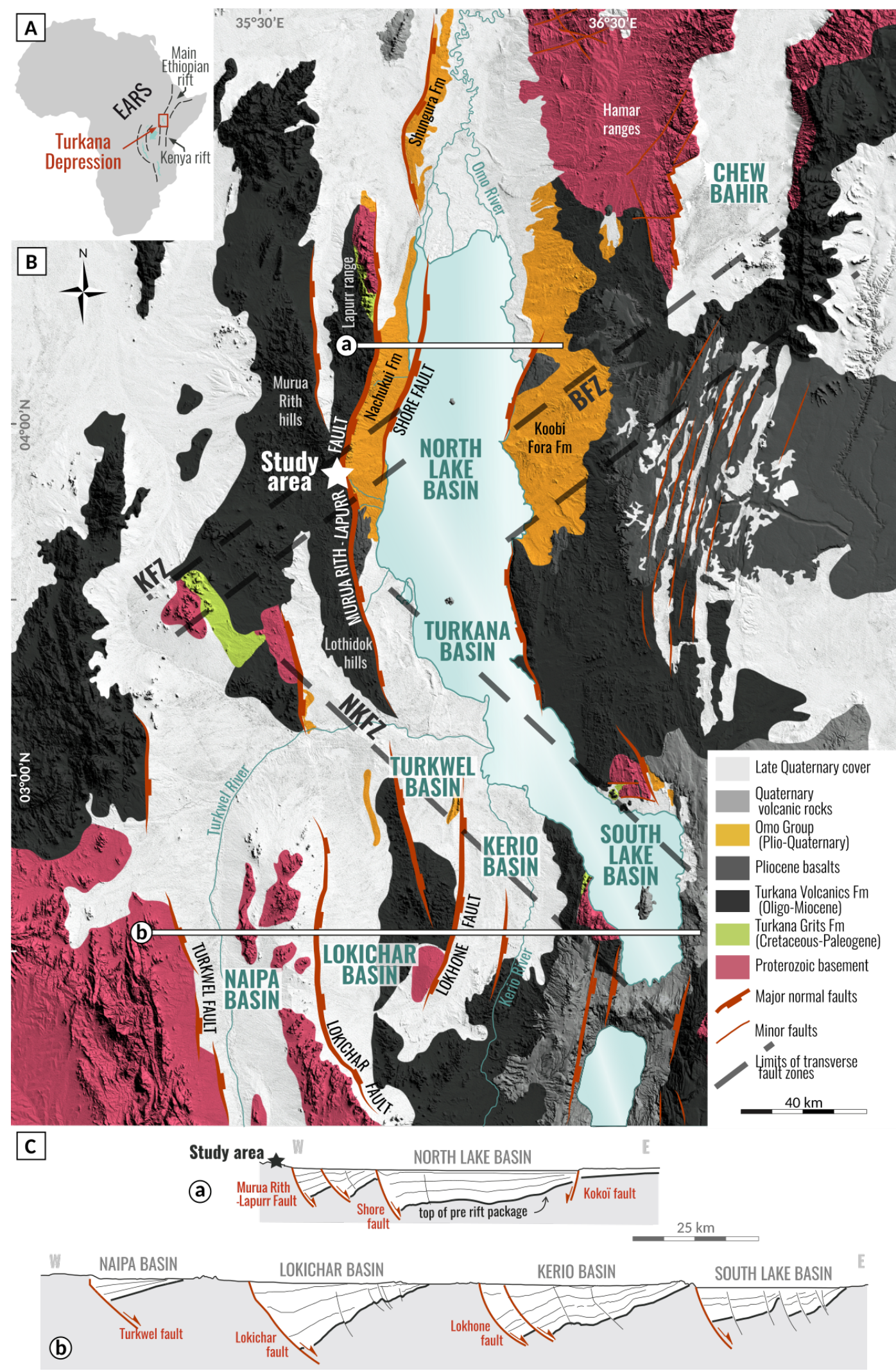

Fig. 1. Structural and geological background of the Turkana Depression. A) Location of the Turkana Depression within the East African Rift System (EARS). B) Geology and main structures of the Turkana Depression compiled from Walsh and Dodson (1969); Wescott et al. (1993); Morley et al. (1999a); Vétel (2005); McDougall and Brown (2009); Jicha and Brown (2014). Main basins and intervening ranges are represented. The study area is located west of the North Lake Basin and is shown with a white star. Background topography derived from SRTM1. C) Large-scale cross-sections showing the grabens and half-graben architectures in the northern (a) and southern (b) Turkana Depression (compiled from Wescott et al., 1999; Morley et al., 1999 and Africa Oil reports, 2016). 
In contrast, the northern part of the Turkana Depression (Fig. 1B), markedly less well known, consists of a single 80-km-wide, >4-km-deep (Abdelfettah et al., 2016) N-S-oriented asymmetric graben known as the North Lake Basin (Fig. 1C; Hendrie et al., 1994; Morley et al., 1999; Tiercelin et al., 2004; Vétel and Le Gall, 2006). The North Lake Basin forms a narrow rift (sensu Buck, 1991) and is bounded to the west by the N-S-oriented Murua Rith-Lapurr Fault (MRLF, Fig. 1B). Eastward of the MRLF, the basin is affected by several minor normal faults followed by a second major fault referred to as the shore fault (Nutz et al., 2017), located along the western shore of present-day Lake Turkana (Figs. 1B, C). West of the MRLF, the North Lake Basin is bordered by a relatively high-relief shoulder known as the Murua Rith Hills and the Lapurr Range. The opening of the North Lake Basin is generally thought to have been initiated between the Upper Miocene ( $9 \mathrm{Ma}$ ) and Middle Pliocene (4.2 Ma) (Morley et al., 1999; Vétel and Le Gall, 2006; Feibel, 2011).

\subsection{Regional stratigraphic framework}

In the Turkana Depression, the basement is composed of metamorphic Proterozoic rocks (Fig. 1, Williamson and Savage, 1986; Morley et al., 1992). Above this basement, both sedimentary and volcanic rocks are grouped into several formations (Fig. 2). The oldest sedimentary rocks, the Turkana Grits, consist of hundreds of meters-thick fluvial sandstones deposited between the Late Cretaceous and Oligocene, and they are found in both the southern and northern portions of the Turkana Depression (Arambourg and Wolff, 1969; Morley et al., 1999; Tiercelin et al., 2004, 2012a and 2012b).

Overlying these older formations, the Turkana Volcanics Formation consists of up to 3-km-thick lava flows occasionally intercalated with volcano-sedimentary rocks that are emplaced over a large portion of the Turkana Depression (Morley et al., 1999; Bruhn et al., 2011). The Turkana Volcanics Fm is interpreted as a response to intense fissural volcanism during the late Eocene to mid-Miocene (Walsh and Dodson, 1969; Bellieni et al., 1981; Zanettin et al., 1983; Bellieni et al., 1987; Boschetto et al., 1992; Morley, 1994; McDougall and Brown, 2009; Bruhn et al., 2011). This volcanism may be related to plume activity, although this remains an issue of debate (Hendrie et al., 1994; Ebinger and

Sleep, 1998; Furman et al., 2004, 2006; Vétel and Le Gall, 2006; McDougall and Brown, 2009; Rooney et al., 2012). In the northern portion of the Turkana Depression (Fig. 1B), the Turkana Volcanics Fm was emplaced between 38 and $28 \mathrm{Ma}$ and after $20 \mathrm{Ma}$ farther to the north (Fig. 2, Bellieni et al., 1987; Morley et al., 1992; Morley et al., 1999; Vétel and Le Gall, 2006). To the south, the Turkana Volcanics Fm disappears progressively and is absent from the Lokichar Basin (Vétel and Le Gall, 2006). 


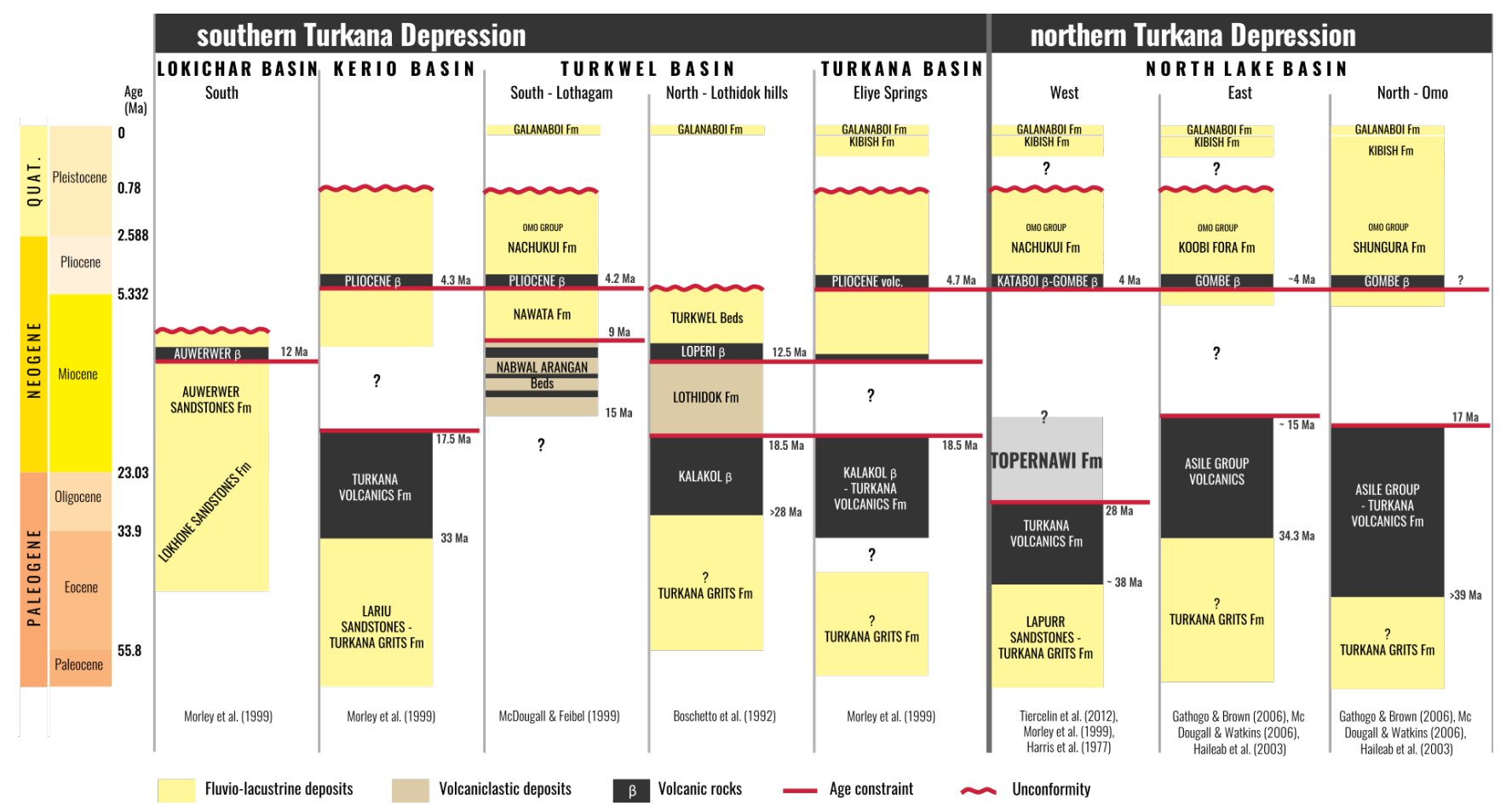

Fig. 2. Lithostratigraphic chart of the Turkana Depression from the southernmost (left) to northernmost basins (right), based on a bibliographic synthesis (references on the figure). The age of the end of the deposition of the Topernawi Fm is discussed in the text.

In the Lokichar Basin, the oldest sedimentary rocks are directly overlain by the Lokhone Sandstones Fm deposited between 38 and $18 \mathrm{Ma}$ (Morley et al., 1999; Tiercelin et al., 2004; Ducrocq et al., 2010). The Lokhone Sandstones Fm is syn-rift in this portion of the depression, revealing that the Lokichar Basin was already active in the Eocene (Morley et al., 1999; Vétel and Le Gall, 2006). Above the Turkana Volcanics Fm and the coeval Lokhone Sandstones Fm, all sediments throughout the Turkana Depression are syn-rift including several formations composed of fluvio-lacustrine sediments, in places intercalated by volcanic rocks (Fig. 2). In the southern Turkana Depression, the syn-rift package includes the early Miocene, mainly sandstone Auwerwer Fm (Morley et al., 1999), the basalts of the Middle Miocene Auwerwer Fm (Morley et al., 1999), the Nabwal Arangan beds (Feibel, 2003) and the Lothidok Fm (Boschetto et al., 1992). These formations are overlain by the Upper Miocene to Lower Pliocene Nawata Fm (Feibel, 2003) and Turkwel beds (Boschetto et al., 1992), which are capped by Pliocene basalts and volcanics. Formations of equivalent age are unknown or absent in the northern Turkana Depression where the Plio-Pleistocene Omo Group is the only known syn-rift deposit. The Omo Group is found throughout the entire Turkana Depression, and it can be subdivided into three main formations: the Nachukui, the Koobi Fora and the Shungura formations (Fig. 2; de Heinzelin, 1983; Harris et al., 1988; Brown and Feibel, 1991; Gathogo and Brown, 2006; Gathogo et al., 2008; Tiercelin et al., 2010; Nutz et al., 2017). At the top of the Omo Group, sedimentation is more disparate and patchy. The most extensive formation is the Kibbish Fm (Butzer and Thurber, 1969), also observed in southern Ethiopia, deposited between the Late Pleistocene and early Holocene (Brown and Fuller, 2008). Finally, the most recent deposits are included in the Galana Boi Fm (Owen 
et al., 1982), consisting of Holocene sediments unconformably overlying older sedimentary formations.

\section{METHODOLOGY}

\subsection{Field geology}

Following remote sensing analyses based on satellite imagery (Landsat, SRTM1, SPOT), we conducted two field surveys, a first in October 2014 and a second in July 2015. We documented contacts between the Turkana Volcanics Fm and the newly recognized sedimentary rocks. The entire basin was mapped for structural and sedimentological features. We measured and analyzed four sections along incised valleys of the Topernawi River and its tributaries. We interpreted lithology, grain size, sorting, bed thickness, sedimentary structures and paleocurrents using conventional facies analysis.

\subsection{Dating}

The timing of the Ekitale Basin evolution was constrained by four samples (Table 1) dated via ${ }^{39} \mathrm{Ar} /{ }^{40} \mathrm{Ar}$ method step-heating using a $\mathrm{CO}_{2}$ laser probe. Whole rock grains were handpicked under a binocular microscope from the $0.5-1.50 \mathrm{~mm}$ fraction. The samples were wrapped in small Al foil package $(11 \times$ $11 \mathrm{~mm}$ ) and stacked. Packages of fluence monitors were inserted every 10 samples. Samples were irradiated under Cd-shielding at the McMaster Nuclear Reactor (Hamilton, Canada). Sample 1 was irradiated for ca. $51 \mathrm{~h}$ at a J/h of ca. $4.4 \times 10^{-5} \mathrm{~h}^{-1}$. The other samples were irradiated for $50 \mathrm{~h}$ at a J/h of ca. $8.2 \times 10^{-5} \mathrm{~h}^{-1}$. Sanidine TCRs (28.608 $\pm 0.033 \mathrm{Ma}$; Renne et al., 1998, 2010) monitored both irradiations.

TABLE 1 Type, location, and age of dated samples

\begin{tabular}{lllllll} 
Sample & Type & Longitude $\left({ }^{\circ} \mathrm{E}\right)$ & Latitude $\left({ }^{\circ} \mathrm{N}\right)$ & Age $(\mathrm{Ma})$ & Age error $(\mathrm{Ma})$ & Reference \\
\hline 1 & Basaltic lava flow & 35.710935 & 3.856604 & 28.4 & \pm 0.1 & This study \\
2 & Dyke, oriented N30 & 35.723138 & 3.8504722 & 25 & \pm 1.8 & This study \\
3 & Dyke, oriented N30 & 35.726444 & 3.8525277 & 25.3 & \pm 0.1 & This study \\
4 & Dyke, oriented N05 & 35.725844 & 3.860048 & 13.9 & \pm 0.1 & This study \\
5 & Basaltic lava flow & 35.72 & 3.854 & 27.9 & \pm 0.3 & McDougall \& Brown, 2009, \\
& & & & & & Sample 98-314
\end{tabular}



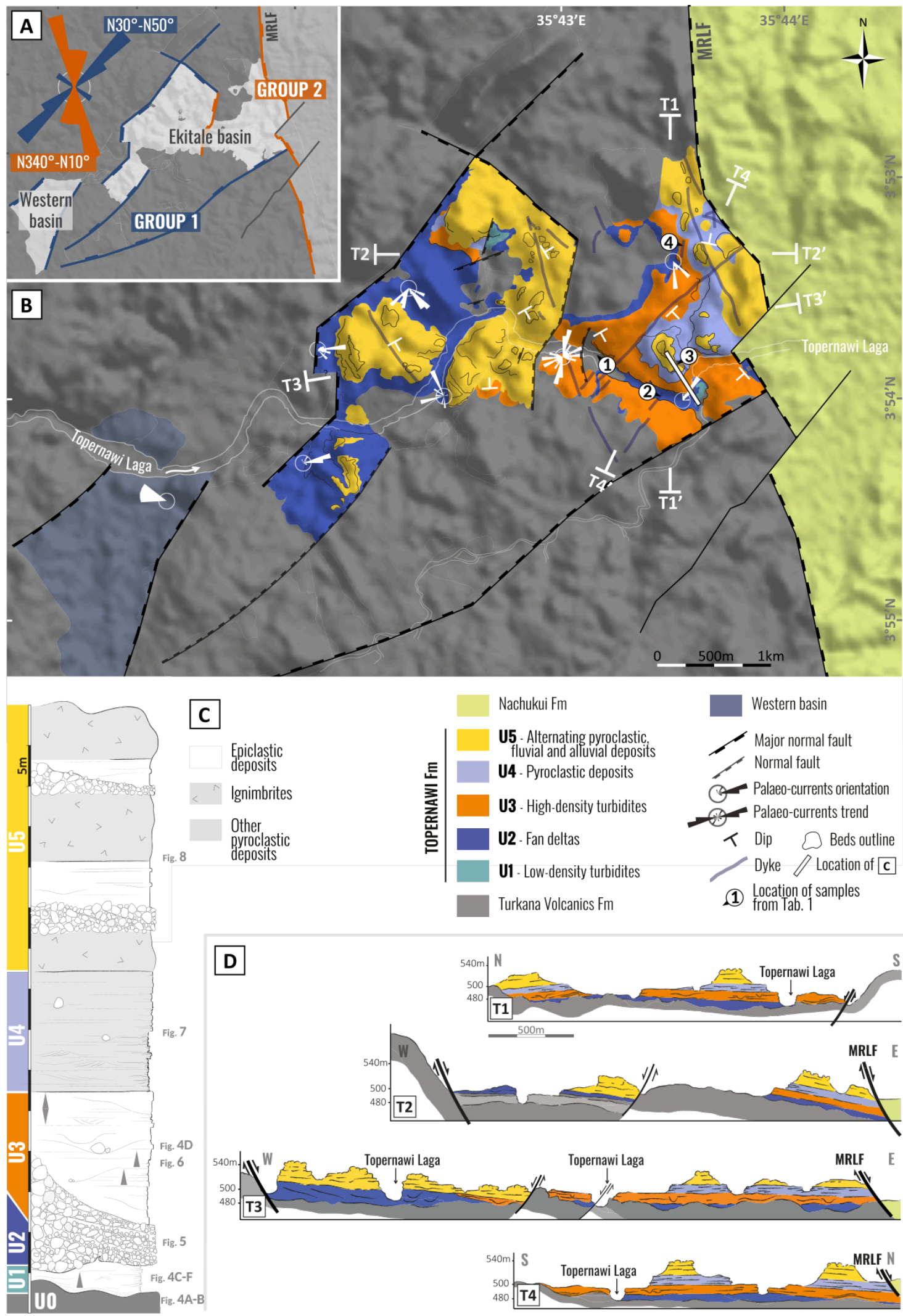

Fig. 3. Detailed geology and structures of the Ekitale Basin. A) Geological map of the Ekitale Basin differentiating the volcaniclastic sediments of the Topernawi Fm (light gray), basalts from the Turkana Volcanics Fm (dark gray) and clastic rocks from the Plio-Quaternary Omo Group (medium gray). Two groups of structures are delineated; Group 1 includes $\mathrm{N} 30^{\circ}-50^{\circ}$ oriented faults and dykes while Group 2 consists of $\mathrm{N} 340^{\circ}-\mathrm{N} 10^{\circ}$ faults and dykes. B) Detailed geology of the Ekitale Basin as mapped by the authors. C) Composite stratigraphic column of the Topernawi Fm with position of relevant figures, see location Fig. 3B. D) Representative cross-sections illustrating the Ekitale Basin architecture and its relationships with the basement. 
We followed the ${ }^{39} \mathrm{Ar} /{ }^{40} \mathrm{Ar}$ method described in Ruffet et al. (1991, 1995). The five argon isotopes and the background baselines were measured in eleven cycles within the peak-jumping mode. Blanks were placed in each first or third/fourth run and then subtracted from the subsequent sample gas fractions. All presented isotopic measurements are corrected for $\mathrm{K}, \mathrm{Ca}$ and $\mathrm{Cl}$ isotopic interference, mass discrimination and atmospheric argon contamination. Apparent age errors are plotted at the 1- $\sigma$ level and do not include errors of the ${ }^{40} \mathrm{Ar}^{\star} /{ }^{39} \mathrm{Ar}_{\mathrm{K}}$ ratio, the age of the monitor nor the decay constant. The errors of the ${ }^{40} \mathrm{Ar}^{*} /{ }^{39} \mathrm{Ar}_{\mathrm{K}}$ ratio, the age of the monitor and the decay constant are, however, included in the final calculation of the (pseudo-)plateau age error margins or for individually cited apparent ages. A Map $215^{\circ}$ mass spectrometer performed the analyses. It is commonly accepted that a plateau is obtained when the calculated ${ }^{40} \mathrm{Ar}^{*} /{ }^{39} \mathrm{Ar}_{\mathrm{K}}$ ratios of at least three consecutive steps, comprising a minimum of $70 \%$ of the ${ }^{39} \mathrm{Ar}$ released, agree within the 1- or 2- $\sigma$ error bars for the weighted mean of calculated ${ }^{40} \mathrm{Ar}^{*} /{ }^{39} \mathrm{Ar}_{\mathrm{K}}$ ratios of the plateau segment. All ages are displayed at the $1-\sigma$ level. Analytical data, parameters used for calculations (isotopic ratios measured on $\mathrm{K}, \mathrm{Ca}$ and $\mathrm{Cl}$ pure salts, mass discrimination, atmospheric argon ratios, J parameter and decay constants) and reference sources are available in a complementary data repository (Fig. S1).

\section{THE EKITALE BASIN}

The Ekitale Basin was identified from the observation of a significant accumulation of sediments west of the Murua Rith-Lapurr Fault (MRLF, Fig. 1B). Mapped sediments of the Topernawi Fm are generally bordered by faults that define a 3-5-km-wide basin directly overlying the Turkana Volcanics Fm. The Ekitale Basin is truncated to the east by the MRLF (Fig. 3B) that constitutes the border fault of the North Lake Basin. The Ekitale Basin thus postdates the emplacement of the Turkana Volcanics Fm and predates the opening of the North Lake Basin. As an initial estimate, the Ekitale Basin opened and evolved between the Late Oligocene and Upper Miocene to Lower Pliocene (Fig. 2). The Ekitale Basin thus belongs to the Cenozoic episode of rifting that affected the northern Turkana Depression.

Here, both the Ekitale Basin and the Topernawi Fm are described in detail. From field observations and stratigraphic correlations, we present a geological map showing the main sedimentary units and structural features (Figs. 3A, B). A lithostratigraphic log (Fig. 3C) illustrates the sedimentary succession and four basin-scale transects expose the current architectural configuration (Fig. 3D). We first describe the basement of the Ekitale Basin. Depositional environments are then reconstructed. We interpret tectonic structures and present a chronology for their emplacement. Finally, we propose a model of the tectono-sedimentary evolution of the Ekitale Basin. 

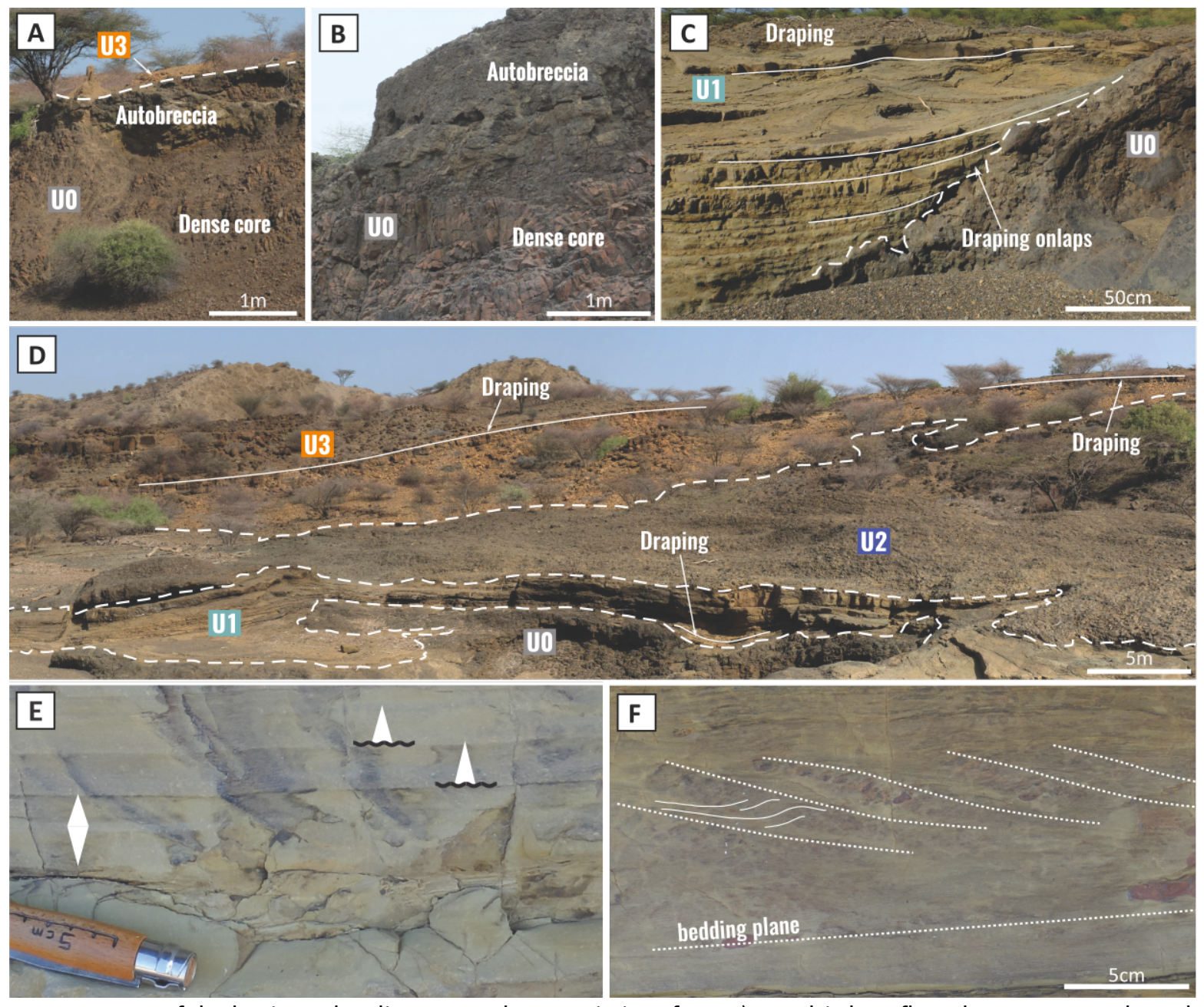

Fig.4. Basement of the basin and sedimentary characteristics of U1. A) Basaltic lava flow that corresponds to the top of the basement (U0) in the central portion of the Ekitale Basin. B) Close-up view of the dense core overlain by top-autobreccia marking the upper limit of the lava flow shown in Fig. 4A. Note the columnar joints in the dense core. C) Draping onlaps of U1 over U0. D) Panoramic view of the central portion of the Ekitale Basin where U1, U2 and U3 crop out. Note the draping patterns of U3 over U0, U1 and U2 and the draping of U1. E) Centimeter-scale fining- and coarsening-up sequences in U1. F) Stoss-depositional climbing ripples in U1, bedding plane and stoss-sides are indicated by dotted lines while lee-sides are illustrated by continuous lines.

\subsection{Basement of the Ekitale Basin}

The basement of the Ekitale Basin (U0) consists of thick basaltic lava flows that belong to the Turkana Volcanics Fm (Fig. 4A). These lava flows are characterized by meter-scale top-autobreccias covering a relative dense core (Figs. 4B, C). Some places show columnar jointing (Fig. 4C). Lava flows are interpreted as a'a-type to rubbly pahoehoe-type (Macdonald, 1953) and indicate subaerial spreading. We observed some intercalated pyroclastic intervals that can be affected by paleosols, reflecting periods of volcanic quiescence. The lava flow marking the top of the Turkana Volcanics Fm in the area is dated to $28.4 \pm 0.1 \mathrm{Ma}$ (Sample 1, Table 1). This age is close to a previous dating of $27.9 \pm 0.3 \mathrm{Ma}$ (Sample 5, Table 1, McDougall and Brown, 2009) attributed to the end of the deposition of the Turkana Volcanics Fm in the area. 


\subsection{Sedimentary infill}

The Topernawi Fm consists of a 75-m-thick sedimentary succession. It is divided into five distinct sedimentary units, named U1 through U5. These sedimentary units are all volcaniclastic rocks, characterized by distinct depositional processes that allow them to be differentiated and traced throughout the basin. We follow the classification scheme of Fisher (1961) who defined three major types of volcaniclastic sediments: 1) pyroclastic deposits resulting from volcanic explosions that extrude discrete particles from volcanic vents; 2) epiclastic deposits composed of fragments produced by the erosion and the redeposition of solidified or lithified volcanic rocks; and 3) autoclastic rocks containing fragments that are produced within (but not usually extruded from) volcanic vents, during the movement of lava flows or by gas explosions within flows that have ceased to flow.

4.2.1 U1 - Complex of low-density turbidites. U1 represents a <4-m-thick package directly overlying the Turkana Volcanics Fm and is mainly observed in the central portion of the Ekitale Basin (Fig. 3C). Where the slope of the underlying Turkana Volcanics Fm is low, U1 drapes the underlaying paleotopography (Figs. 4C, D). In locations where the slope is steeper, U1 intersects U0 in the form of draping onlaps (Fig. 4C). U1 consists of volcaniclastic sediment in $\mathrm{cm}$-scale planar laminations comprised predominantly of erosion-based, fining-up sequences with occasional coarsening-up sequences (Fig. 4E) that grade from fine sand- to silt-sized grains. We also observed stoss-depositional climbing ripples (Ashley, 1982) in places (Fig. 4F). Abundant mm- to cm-scale wood and coal debris is found within the sediment. Soft-sediment deformations are observed at the top of U1 marking an uneven boundary with U2 (Fig. 5C).

Fining-up and coarsening-up intervals (Fig. 4E) are interpreted as sediments deposited during the waxing and waning flow, respectively, of turbidity currents (Mulder and Alexander, 2001; Mulder et al., 2001; Mulder et al., 2003; Talling et al., 2012). Stoss-depositional climbing ripples (Fig. 4F) reflect unidirectional flow associated with high suspended loads, a feature also compatible with low-density turbidity currents (Jobe et al., 2012; Talling et al., 2012). The general draping pattern of U1 (Fig. 4D) suggests either a subaqueous deposition or deposition from hot pyroclastic flows. The lack of fiammes, ballistic clasts and accretionary lapilli, normally associated with hot genetic flows, supports the interpretation of water-related turbidity currents. Furthermore, soft-sediment deformations along the top boundary of U1 occur in water-saturated sediments (Owen, 1996; Owen and Moretti, 2011) and confirm a subaqueous depositional environment. Thus, we conclude that $\mathrm{U} 1$ is composed of epiclastic rock (Fisher, 1961; Pettijohn et al., 2012) deposited by low-density turbidity currents originating from the distal sedimentation of a turbiditic complex related to a sediment-laden river flowing (Mulder et al., 2003; Zavala et al., 2011) into a standing waterbody. Moreover, the presence of abundant woody debris suggests that water drained a vegetated subaerial area, again supporting this interpretation (Zavala et al., 2012). 

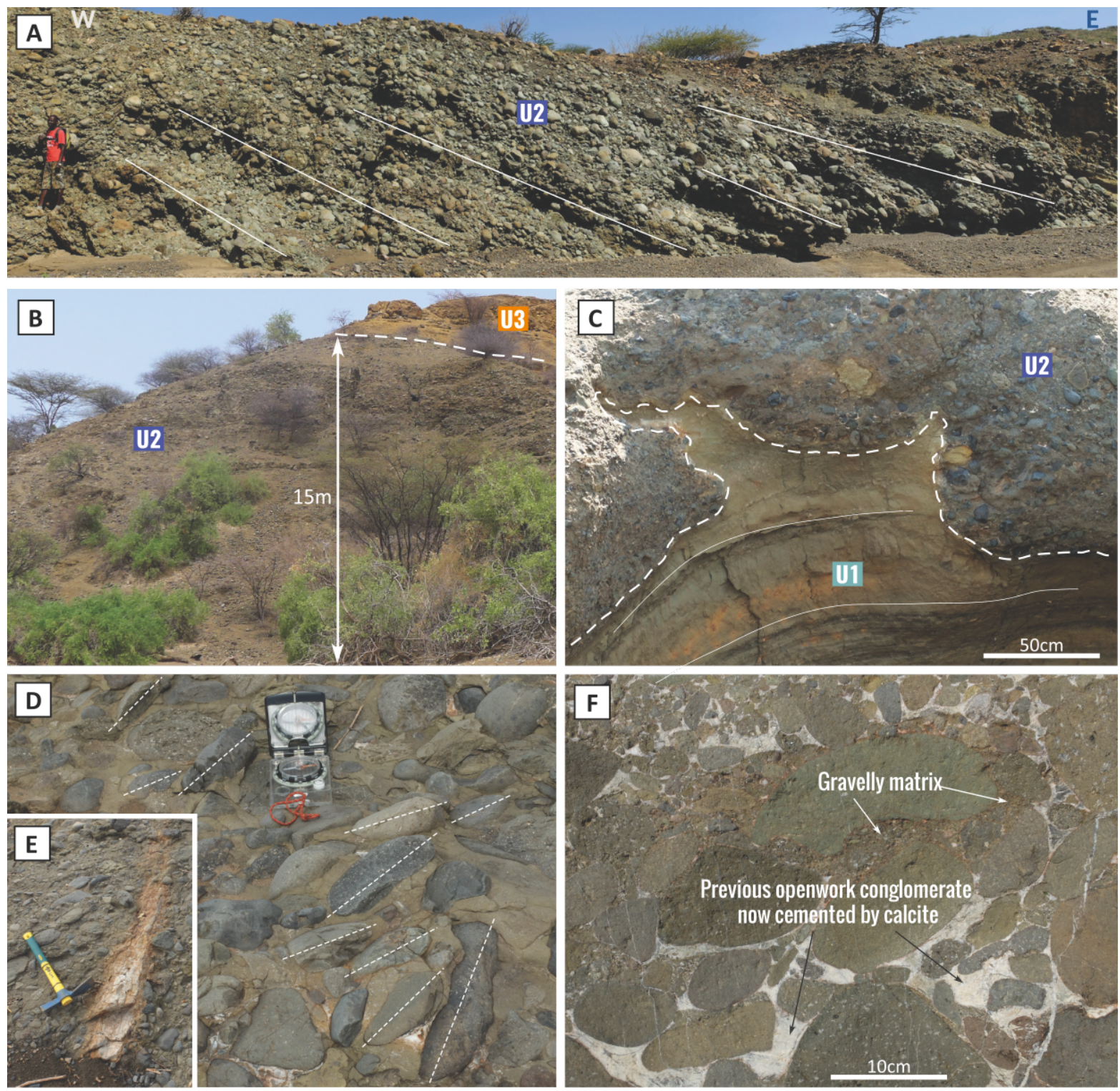

Fig. 5. Sedimentary characteristics of U2. A) Basinward dipping, high-angle cross-stratifications in the coarse conglomerate. B) Coarse conglomerate of U2 conformably overlain by U3 near the northwestern faulted border of the basin. C) Irregular contact between U1 and U2 showing recurrent post-depositional intrusions of U1 into U2. D) Oriented and imbricated basaltic clasts. E) Wood trunk remnant. F) Coarse conglomerate showing partial precipitated calcite cement testifying to previous openwork.

4.2.2 U2 - Alluvial fan deltas. U2 is a clast-supported conglomerate (Fig. 5). U2 consists of plurimetric wedge forms up to 15-m-thick that fringe the northwestern border faults. This unit thins laterally to 12-m-thick toward the central portion of the basin (Fig. 5A). Clasts consist of 2-30 cm well-rounded and relatively well-sorted basalts and phonolites (Fig. 5D, F), while the matrix consists of gravelly to coarse sand-sized material (Fig. 5F). The lower boundary of this unit is irregular due to recurrent intrusions of U1 into U2 (Fig. 5C). U2 often displays relatively high-angle oblique stratifications ( $15^{\circ}-$ $35^{\circ}$ ) that dip basinward (Fig. 5A). Imbricated clasts indicate a paleoflow direction toward the central portion of the basin (Fig. 5D). In places, an openwork conglomerate is observed (Fig. 5F) as well as 
plurimetric channel forms that occasionally scour the oblique stratifications. Finally, pluridecimetric silicified woody debris is common, including fossil wood trunks up to 1-m-long (Fig. 5E).

The wedge-form, basinward oblique stratifications are interpreted as foreset beds prograding from the basin margins toward the central portion (Figs. 5A, B). Very large clasts (Fig. 5D, E) indicate a transport by relatively high-energy flows over a short distance. The maximum thickness of clinoforms close to border faults testify to a genetic linkage to these border faults. We interpret this unit as epiclastic rocks deposited as alluvial fans that partly fringed the basin. The intrusions of U1 into the overlying $\mathrm{U} 2$ relate to the presence of saturated sediments that reflect a subaqueous environment where U2 is deposited onto U1 (Fig. 5C). Openwork conglomerates (Fig. 5F) also support our interpretation of a subaqueous environment where the winnowing of the conglomerate matrix can be related to subaqueous currents or waves in the nearshore to shoreface domains (Hart and Plint, 1995). The subaqueous emplacement of the foreset beds indicates that these alluvial fan deltas deposited along the shore of a standing waterbody. Occasional high-angle foreset bedding suggests that these alluvial fan deltas developed into, at least episodically, Gilbert-type fan deltas (Postma, 1990), reflecting periods of higher lake stands. These alluvial fan deltas correspond to syn-tectonic deposits having been directly fed by the dismantling of the topography created by border fault activity.

4.2.3 U3 - Complex of high-density turbidites. U3 consists of a 20-m-thick tabular interval draping the underlying U0, U1 and U2 units (Fig. 4D). U3 consists of volcaniclastic sand- to gravel-sized sediments. Planar beds were dominant although they were frequently reworked by <10-m-large and 1-4-m-thick channel forms (Figs. 6A, B, C). Planar beds include erosion-based, fining-up sequences that are occasionally associated with coarsening-up, dm-scale sequences composed of gravel- to sand-sized grains (Fig. 6D). Parting lineations are frequently observed in the sand-sized material (Fig. 6E). In places, planar beds are composed of cm-scale pebbles (Fig. 6C). Channel forms are generally filled by slightly coarser material than the surrounding planar beds (Fig. 6F). They consist of massive to faintly laminated beds of coarse sand-sized grains to pebbles in dm-scale fining-up sequences. These sequences are occasionally associated with cross-stratifications and current ripples. In places, channel forms include outsized clasts of more than $>20 \mathrm{~cm}$ that underlie the basal erosion (Fig. 6C). In places, gutter casts affect the bottom surface of some channel forms. Finally, silicified cm- to $\mathrm{m}$ scale wood debris, trunks and coal clasts are often found within both the channels and planar stratifications. 

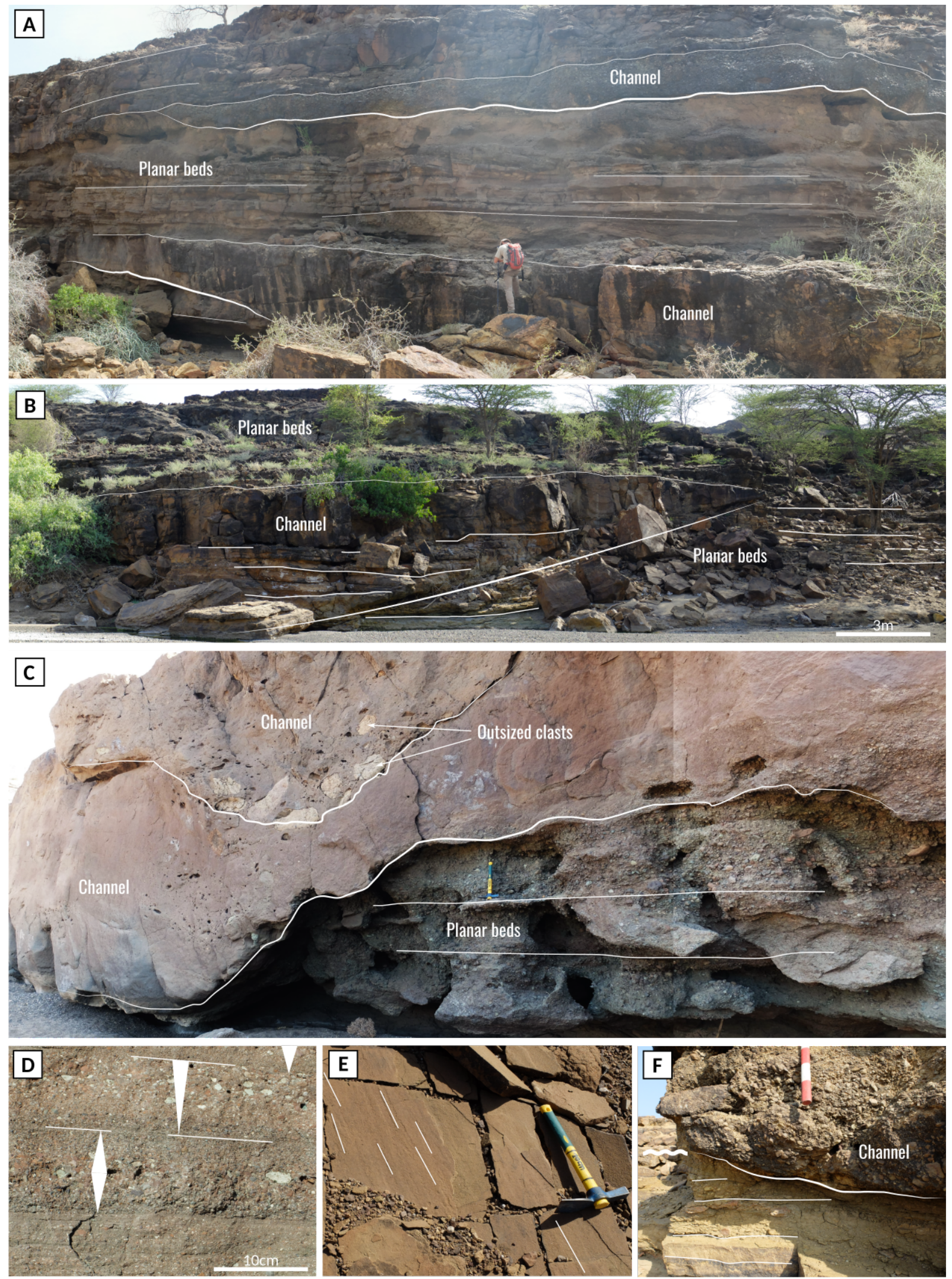

Fig.6. Sedimentary characteristics of U3. A), B) and C) Alternations of planar and channelized intervals. Channels are faintly laminated to massive and occasionally outsized boulders underline the erosional trough. D) Decimeter-scale fining- and coarsening-up sequences in planar beds. E) Parting lineations in planar beds. F) Channelized medium conglomerate that eroded the underlying planar beds. 
The fining- and coarsening-up sequences (Fig. 6D), found in both the planar beds and channel forms, are interpreted as the waxing and waning flows, respectively, of turbidity current deposits (Mulder and Alexander, 2001; Mulder et al., 2001; Mulder et al., 2003; Talling et al., 2012). As with U1, the general draping pattern of U3 over the underlying units (Fig. 4D) suggests either a subaqueous deposition or a deposition from hot pyroclastic flows. Again, the absence of any indicators for hot genetic flows supports subaqueous turbidity currents as the origin of U3. In places, a waxing sequence directly overlies a waning sequence (Fig. 6D). The preservation of deposits related to the waxing flow (Fig. 6D) is traditionally associated with hyperpycnites, as opposed to gravity-driven turbidites. The latter are characterized by a quasi-instantaneous peak flow followed by a waning flow to generate a sedimentation dominated by inversely graded sequences (Mulder et al., 2003). This interpretation is also supported by the abundant wood remains, testifying to the drainage of subaerial areas by rivers and deposition into a paleolake. Massive to faintly laminated material, including the outsized clasts in the channel forms, are attributed to debris flow to high-density turbidity currents (Kneller, 2003; Mutti et al., 2003; Talling et al., 2012). Thus, U3 consists of epiclastic sediments deposited in the form of both high-density turbidites and debrites (Talling et al., 2012) related to debris flows, high-density flows and high-energy river flows entering a paleolake. The alternating planar and channelized beds are related to variable energetic conditions associated with the successive turbidity currents. The channel forms (Figs. 6A, B, C, F) reflect laterally confined turbidity currents and a relatively greater energetic flow from more powerful flood events (Wright, 1977). Planar beds develop from flows in the more distal domain or during less energetic flows. We interpret $\mathrm{U} 3$ as a complex of proximal to intermediate turbidites in a sub-lacustrine environment.

4.2.4 U4 - Pyroclastic deposits. U4 consists of a >20-m-thick succession conformably overlying U3 (Fig. 7A). It is composed of volcaniclastic sediments, reddish medium sand-sized grains alternating with whitish gravelly-sized to coarse sand-sized grains in dm-scale beds (Figs. 7A, B). In the lower portion of the unit, beds are 0.1-0.3-m-thick and usually include alternating planar and low-angle oblique tangential laminations, generally westward dipping at $10^{\circ}-15^{\circ}$ (Fig. 7B). Low-angle oblique tangential laminations are truncated up-dip and are overlain by relatively continuous layers that drape over the upper undulating surface, slightly thickening above the truncated laminations (Fig. 7B). In the upper portion, planar laminations dominate. Centimeter- to dm-scale clasts are common in the sandy sediments. Laminations show asymmetric plastic deformation below the clasts (Fig. 7C). In places, $\mathrm{U} 4$ includes $\mathrm{cm}$-scale beds of $1-3-\mathrm{mm}$-diameter spherical clasts that have concentric laminations (Figs. 7D, E). 

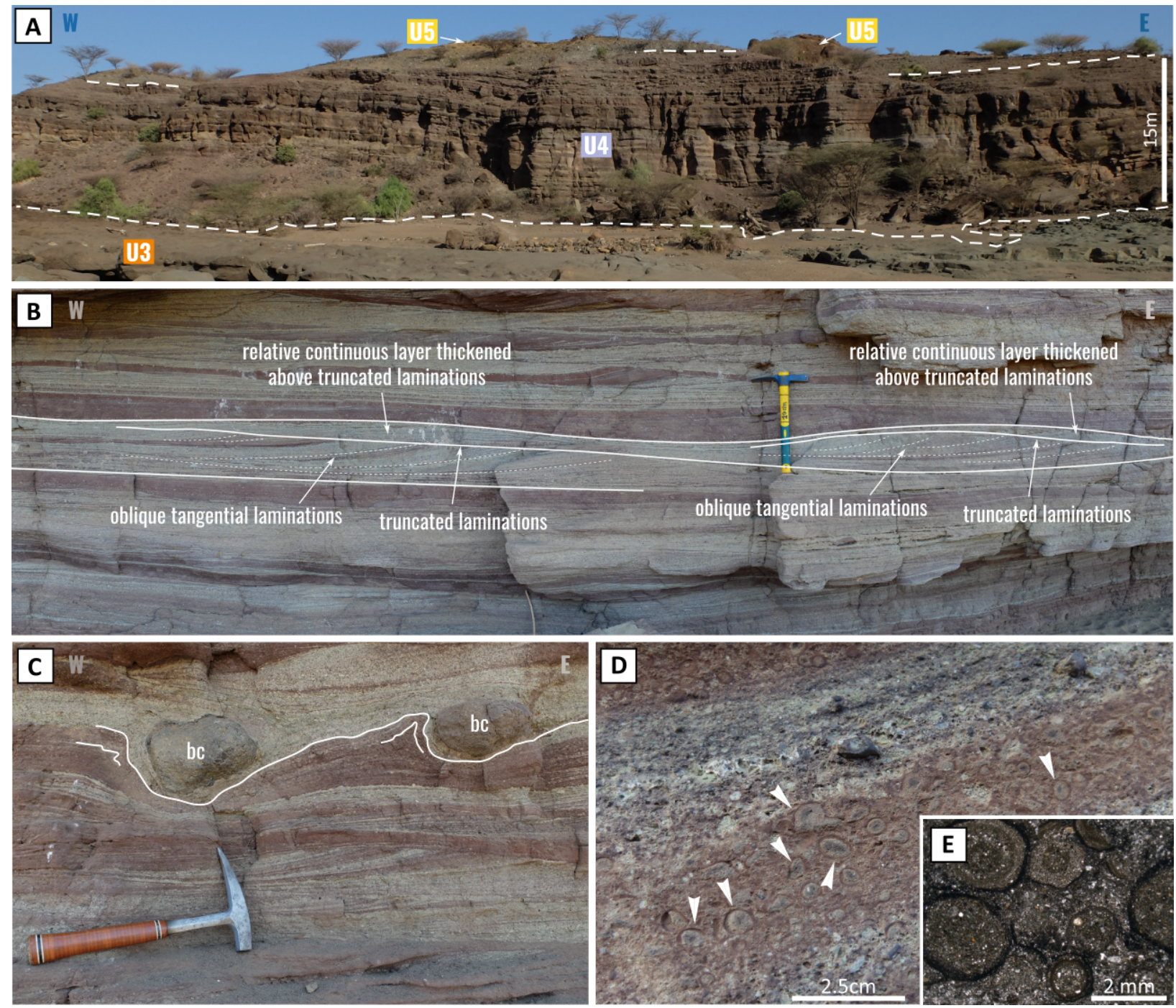

Fig. 4. Sedimentary characteristics of U4. A) U4 conformably overlies U3, and is overlain by U5 in the central portion of the basin. B) Detail of dunes in the lower part of U4. They are characterized by dm-scale tangential cross-laminations. C) Decimeter-scale ballistic clasts (bc). D) Example of a cm-scale bed composed of spherical clasts (white arrow heads). E) Thin sections of spherical clasts characterized by concentric micro-laminations interpreted as accretionary lapilli.

We interpret the floating clasts as ballistic clasts (Cas and Wright, 1988) and the spherical clasts within the cm-scale beds as accretionary lapilli (Gilbert and Lane, 1994). Thus, we consider U4 as a pyroclastic deposit. Alternations of planar and low-angle oblique laminations (Fig. 7B) reflect the alternating development of upper-stage plane beds and dunes and relate to alternating sub- and supercritical flows (Schmincke et al., 1973; Alexander et al., 2001; Fielding, 2006; Duller et al., 2008). This dune bedding has numerous similarities with the progressive 'type A' dunes of Cole (1991), interpreted as pyroclastic-surge deposits. The orientation of the dunes and the direction of the asymmetric deformations below the ballistic clasts also support a pyroclastic flow originating from the east. We interpret U4 to be a base surge deposit (Waters and Fisher, 1971; Wohletz and Sheridan, 
1979; Walker, 1984; Moorhouse and White, 2016) attributed to pyroclastic flows (Waters and Fisher, 1971; Fisher and Schmincke, 1984).

4.2.5 U5 - Alternating pyroclastic, fluvial and alluvial deposits. U5 is a 30-50-m-thick sedimentary unit. Conformably overlying U4, U5 can be traced throughout the basin by its yellow to purple color stemming from an intense weathering that is also responsible for frequent observations of spheroidal weathering (Fig. 8B) in the uppermost part of the succession. U5 is composed of volcaniclastic sediments. In places, the primary sedimentary structures are difficult to observe; however, we can divide U5 into three main facies. The first facies association consists of sand-sized grains including $\mathrm{mm}$ - to $\mathrm{cm}$-scale floating angular clasts and frequent fiammes in structureless to faintly stratified plurimetric-scale tabular intervals (Figs. 8A, C, D, E). The second facies association is comprised of horizontally stratified gravels in plurimetric-scale tabular intervals (Figs. 8A, C, F). The tabular intervals are recurrently incised by channel forms filled mostly by clast-supported conglomerate composed of well-sorted cm-scale rounded to well-rounded pebbles (Fig. 8F). The third facies association is a matrix-supported coarse conglomerate (Figs. 8C, G) included within $>10$-m-thick wedges. These wedges are particularly well developed near the border faults of the basin (Fig. 8G) and pinch out toward the central portion. Large-scale oblique stratifications are observed on occasion (Fig. 8G). These conglomeratic intervals contain abundant silicified wood remains and coal debris.

The structureless and faintly stratified pattern coupled with the absence of a muddy matrix suggest that the first facies association was formed by deposits from high-density turbidity currents (Mulder and Alexander, 2001). Fiammes testify to hot genetic flows; thus, the first facies association reflects ignimbrites (Smith, 1960; Wilson and Walker, 1982) deposited by pyroclastic flows. The sorting of clasts within the channel forms of the second facies association suggests a relatively long-term transport by dilute flow. We interpret channel forms as evidence of fluvially remobilized pyroclastic material. The horizontally stratified tabular beds are inferred as overbank deposits associated with fluvial floods. Finally, coarse conglomerate within the third facies association testifies to high-energy and short-distance transport. The maximum thickness of this facies along the basin margins suggests a genetic connection with border faults. We interpret the wedge-shaped, large-scale oblique stratifications as foresets similar to those in U2. The clinoforms are interpreted as alluvial fan progradation genetically related to border fault activity. Finally, U5 includes alternating deposits from pyroclastic events, fluvial drainage in the central portion of the basin during volcanic quiescence (Fig. 8C) and alluvial fan development during border fault activity. Weathering in U5 (intense and spheroidal) testifies to a long-term exposure of the uppermost surface after its deposition. 

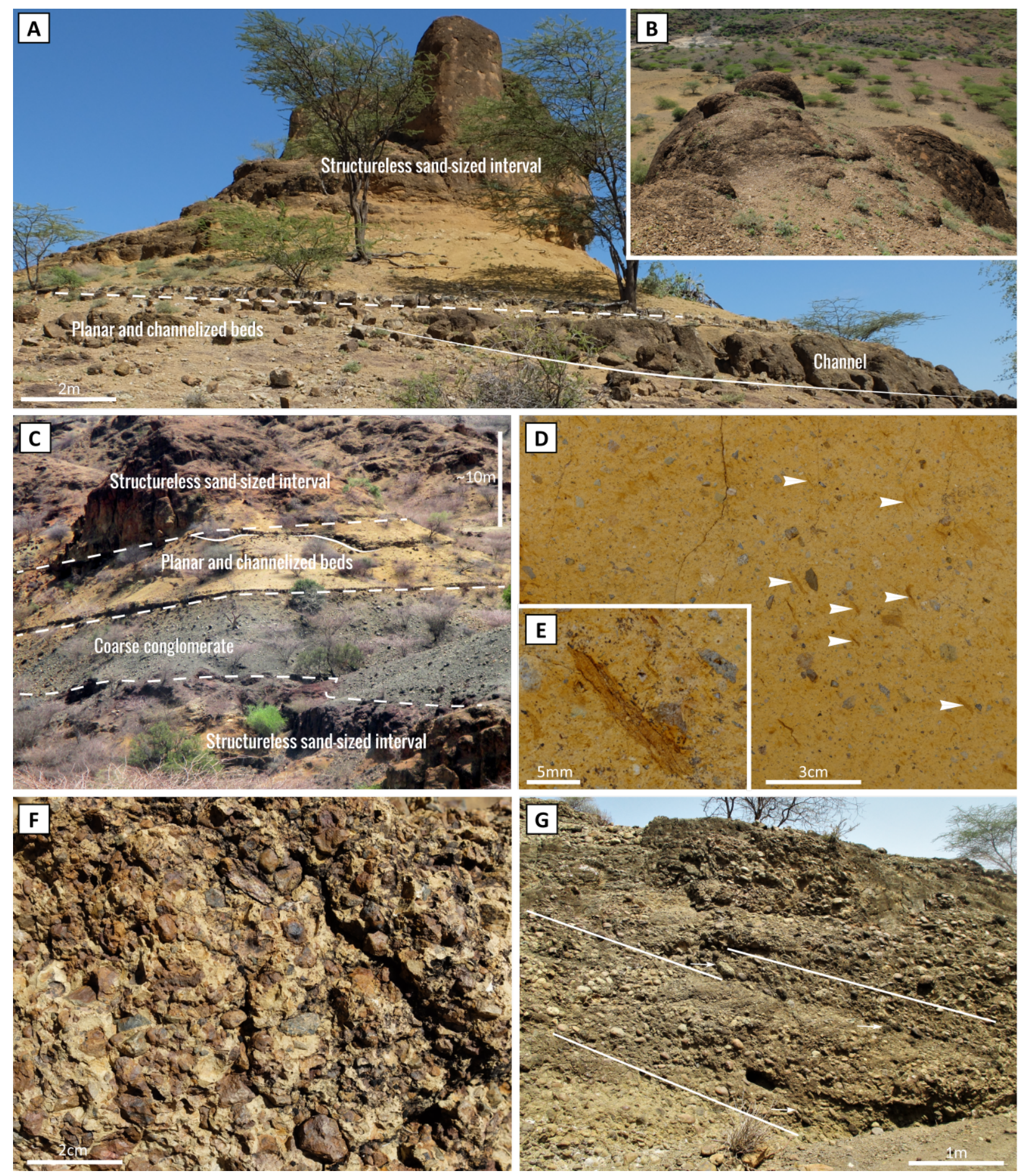

Fig. 8. Sedimentary characteristics of U5. A) Yellow to purple sediments corresponding to the uppermost part of U5 in the central portion of the basin. This includes gravel- to pebble-sized material in planar and channelized beds (second facies association) conformably overlain by structureless sand-sized material (first facies association). B) Spheroidal weathering at the top of U5 affecting the structureless sand-sized material. C) Yellow to purple sediments of U5 displaying alternations of intervals made of structureless sand-sized material (first facies association), gravel- to pebble-sized planar and channelized beds (second facies association) and coarse conglomerate (third facies association). D) Details of structureless sand-sized material composed of $\mathrm{mm}$ - to cmscale floating sub-angular to angular clasts and fiammes (white arrows) in sand-sized material. E) Close-up view of a fiamme. F) Mostly clast-supported fine conglomerate in a channelized form (second facies association). G) Thick and coarse conglomerate located near the border fault of the basin showing internal large-scale oblique stratifications. Imbricated clasts are highlighted with white arrows. 
4.2.6 Synthesis - The stratigraphic units indicate that two main phases of sedimentation occurred in the Ekitale Basin. The first phase is characterized by the appearance and evolution of a lacustrine system directly overlying the Turkana Volcanics Fm. This lake was fed by alluvial and fluvial systems (U1, U2, U3) and thereby shows that the Ekitale Basin contained a small river-driven lake (sensu Nutz et al., 2016). During this period, border fault activity was relatively important, and the Ekitale Basin was underfilled permitting accommodation space and allowing the development of a perennial lake. During the second phase, the prevalence of pyroclastic deposits indicates a renewal of local volcanism. Punctual pulses of fault activity, expressed by alluvial fans in U5, continued to create accommodation space for sedimentation. However, this second phase is characterized by excessive sediment supply compared to accommodation space, and the Ekitale Basin became overfilled. This led to the disappearance of the former lake and to a sedimentation dominated by volcanic events and fluvial/alluvial deposits. Finally, there was a long-lasting non-depositional period inferred from the intense weathering at the top of U5, suggesting that sedimentation was interrupted after the deposition of U5. The Topernawi Fm is believed to have recorded the complete history of the basin.

\subsection{Structural characterization}

We identified numerous faults and volcanic dykes in the Ekitale Basin through remote sensing and field mapping. According to their relationships with sediments of the Topernawi Fm and their

orientation, we divided these faults and dykes into two main structural groups referred to as Group 1 and Group 2.

4.3.1 Group 1. This group includes $\mathrm{N} 30^{\circ}-50^{\circ}$-oriented normal faults that systematically separate rocks of the Turkana Volcanics Fm-forming footwalls-from rocks of the Topernawi Fm, which correspond to hanging walls (Fig. 3B). To the north, a $3.5-\mathrm{km}$ and $6-\mathrm{km}-1$ long SE-dipping normal faults oriented $\mathrm{N} 40^{\circ}$, mark the limit of the Ekitale Basin (Fig. 3B). To the south, the Ekitale Basin is bordered by a 6$\mathrm{km}$-long NW-dipping normal fault oriented N50 (Fig. 3B). Along both the northern and the southern limits, the faults are marked by escarpments of ten to several tens of meters high (Fig. 9A). A 3-kmlong segment of the northern limit consists of a N140 normal fault. This fault separates the Turkana Volcanics Fm from the Topernawi Fm, and we thus included this in Group 1. Finally, two N30 $-40^{\circ}$ trending normal faults, 2 and 4-km-long, delineate the western basin (Fig. 3A) and are thus included in Group 1. 


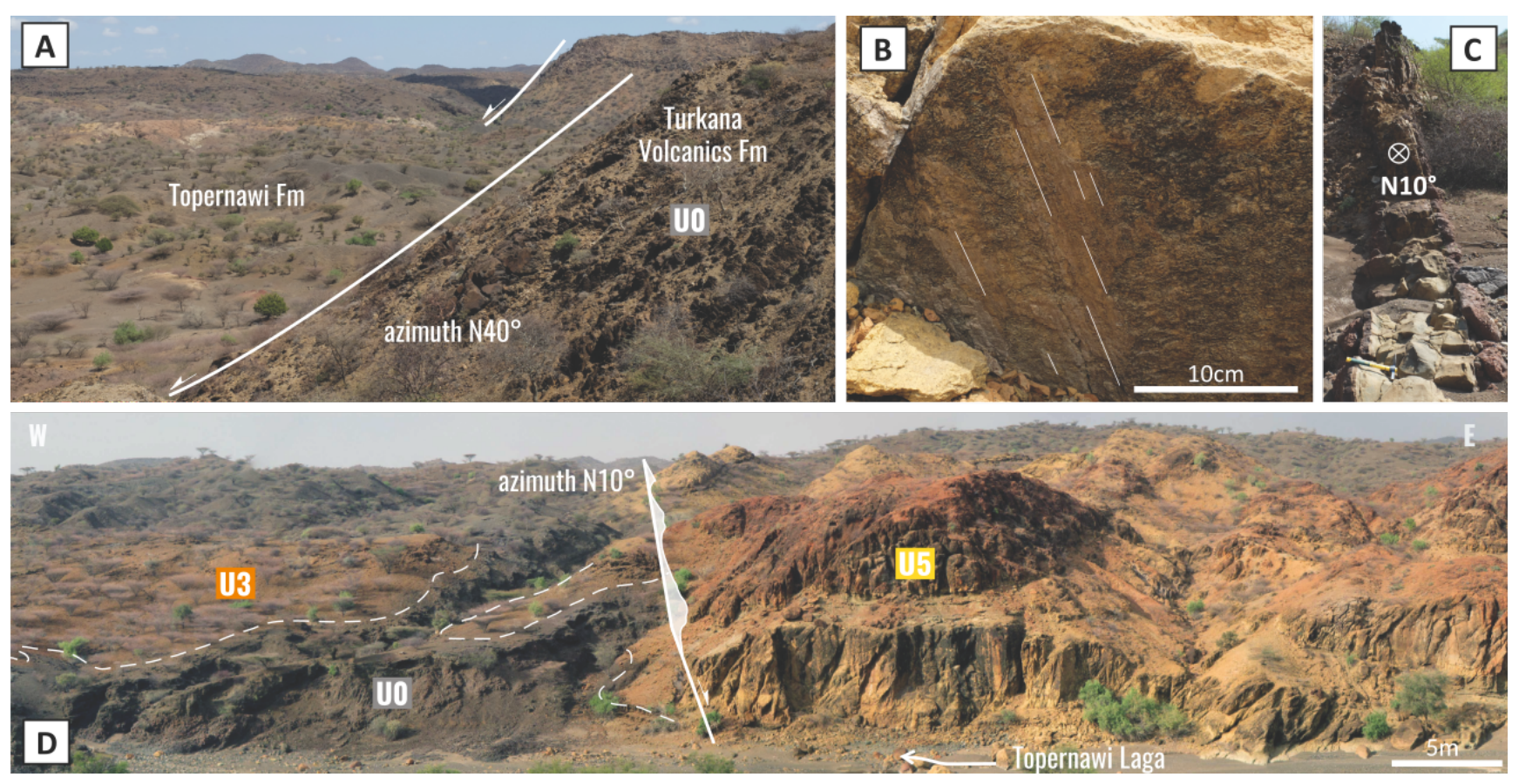

Fig. 9. Examples of structural characteristics of the Ekitale Basin. A) Group 1 normal fault at the northern limit of the basin. The escarpment is $50 \mathrm{~m}$ high and separates the Turkana Volcanics Fm (U0) from the Topernawi Fm. B) Striations on the plane of the fault shown in Fig. 9D (Group 2) highlighting a dip-slip movement. C) Example of basaltic dyke cross-cutting the Topernawi Fm. The dyke is oriented $\mathrm{N}^{\circ}$ and is included in the Group 2 structures. D) Example of a Group 2 normal fault cross-cutting the Topernawi Fm in the central portion of the basin.

Structures belonging to Group 1 limit both the Ekitale and western basins and never truncate the sedimentary infill. Thus, Group 1 structures are not posterior to the deposition of the Topernawi Fm. Moreover, the genetic relationship between the normal faults of Group 1 and the development of alluvial fans in units U2 and U5 testifies to a recurring pulsed activity of Group 1 normal faults during the deposition of the Topernawi Fm. Thus, Group 1 normal faults are syn-sedimentary structures. Group 1 structures created the accommodation space necessary for the deposition of the Topernawi Fm. Worth noting, the dominant orientation of the Group 1 structures $\left(\mathrm{N} 30^{\circ}-50^{\circ}\right)$ is similar to the orientation of structures belonging to the basement-inherited fault zones KFZ and BFZ (Vétel, 2005; Vétel and Le Gall, 2006). We thus interpret the development of Group 1 structures to be associated with the extensional reactivation of pre-existing structures. The N140 segment, incorporated in Group 1, is attributed to the reactivation of conjugate structures. Structures of similar orientation are identified both in the KFZ and BFZ (Vétel, 2005; Vétel and Le Gall, 2006).

4.3.2 Group 2. The second group includes both normal faults and volcanic dykes. They differ from Group 1 structures as they systematically cross-cut the Topernawi Fm. Most of the structures are oriented between $\mathrm{N} 340^{\circ}$ and $\mathrm{N} 10^{\circ}$ highlighting a general $\mathrm{N}-\mathrm{S}$ orientation. Two main normal faults are included in this group (Fig. 3A). The first corresponds to the MRLF fault that borders the Ekitale Basin to the east. In the study area, the MRLF is oriented $\mathrm{N} 350^{\circ}$ and truncates the Topernawi Fm (Figs. 3A, B), separating the current rift shoulder from the North Lake Basin (Fig. 1B). The second is located 2- 
$\mathrm{km}$-westward and consists of a 2-km-long N10 west-dipping normal fault (Fig. 3B). This fault crosscuts the entire Topernawi Fm with a vertical offset of $10 \mathrm{~m}$ (Figs. 9B, D). In addition, most of the basaltic dykes (Fig. 9C) that truncate the entire Topernawi Fm are oriented between $\mathrm{N} 340^{\circ}$ and $\mathrm{N} 10^{\circ}$ and are thus included in Group 2. One of these dykes has been dated at ca. $14 \mathrm{Ma}$ (Sample 4, Table 1). Yet, $\mathrm{N} 30^{\circ}-40^{\circ}$-oriented dykes that share orientations with Group 1 structures-rather than the usual Group 2 orientations-have also been identified. Two of them have been dated ca. 25 Ma (Samples 2 and 3 , Table 1).

All normal faults and dykes belonging to the Group 2 cross-cut the Topernawi Fm and thus postdate the deposition of the Topernawi Fm, as opposed to Group 1 structures. Group 2 normal faults reflect a more recent extensional episode. This second extensional event led to previously active faults being abandoned and the generation of new, broadly N-S-oriented structures in the Ekitale Basin. One of these Group 2 structures is the MRLF that started to develop with the opening of the North Lake Basin (Vétel and Le Gall, 2006). Thus, N-S-oriented structures included in Group 2 are interpreted as being coeval with the opening of the North Lake Basin and more generally with the pervasive development of N-S-oriented basins in the Turkana Depression. Having a similar range of orientations, N-Soriented dykes are interpreted to have developed broadly coeval to the Group 2 normal faults and thus to the opening of the North Lake Basin. Furthermore, N30 -40 -oriented dykes are oriented in a similar manner as the Group 1 structures, suggesting they are associated to another event. This is supported by absolute ages (Table 1 ) confirming that the $\mathrm{N} 30^{\circ}-40^{\circ}$ and $\mathrm{N}$-S-oriented dykes were emplaced during two separate events dated at ca. $25 \mathrm{Ma}$ and ca. $14 \mathrm{Ma}$, respectively. 
(A)

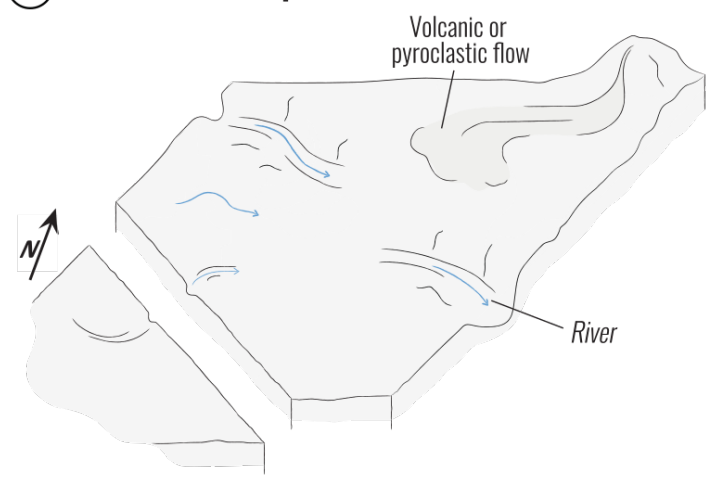

C Fault growth and climax of alluvial fans development

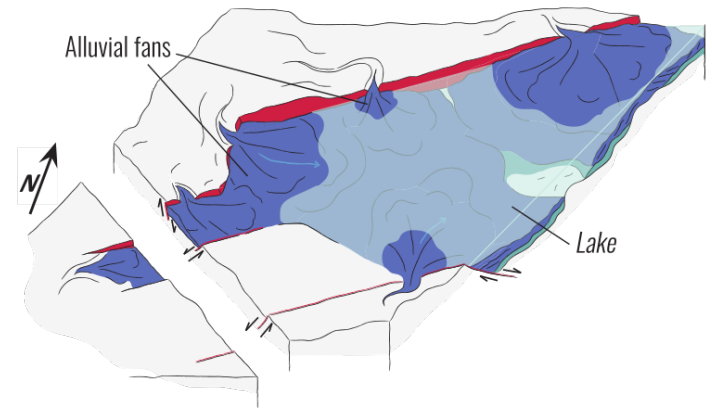

(E) Onset of intense volcanism

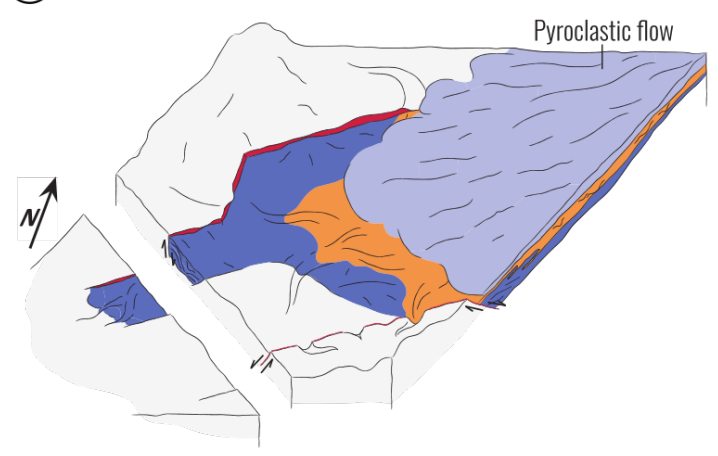

(G) After $25 \mathrm{Ma}$ - Abandonment of the Ekitale basin

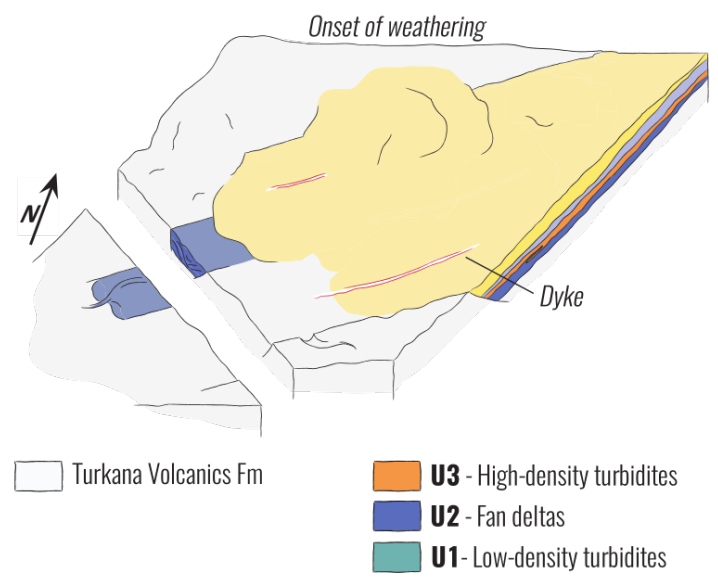

(B) Opening of the Ekitale basin and lake formation

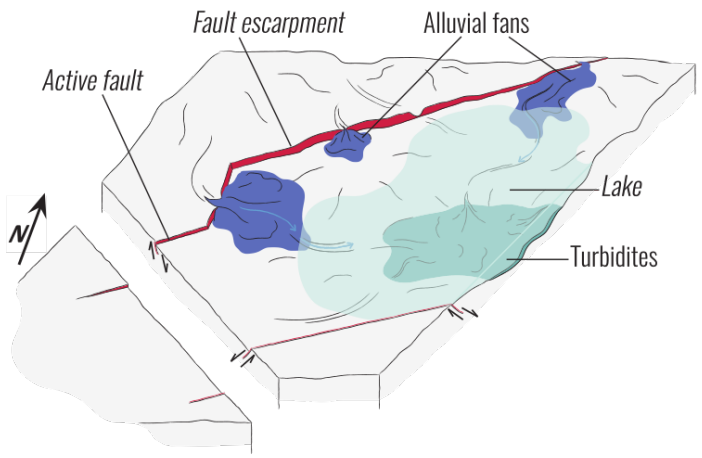

(D) Capture of a main river, deposition of turbidites

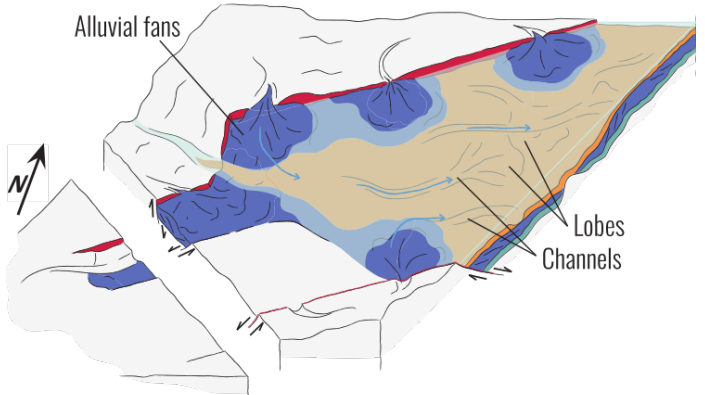

(F) Intermittent volcanism, fluvially reworked

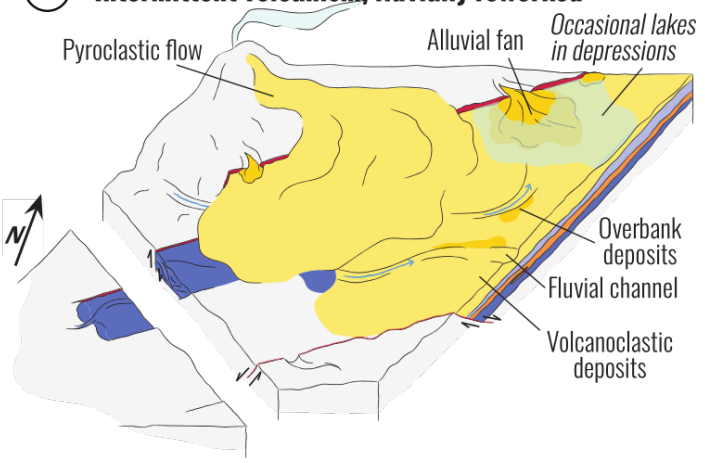

(H) $\sim 14$ Ma - Opening of the North Lake basin

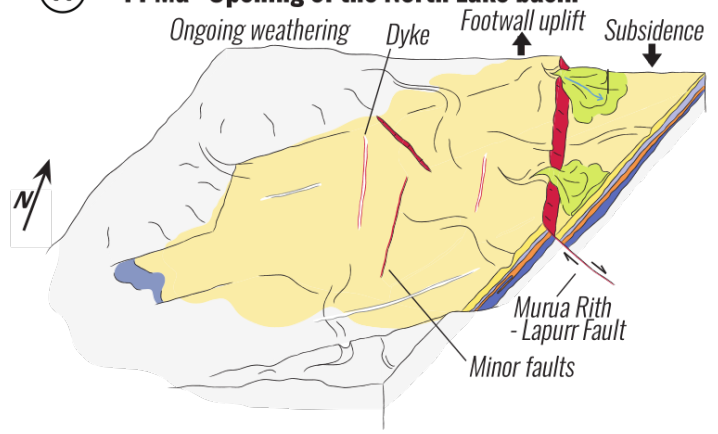

U5 - Alternating pyroclastic, fluvial and alluvial deposits

$\mathbf{U} 4$ - Pyroclastic deposits

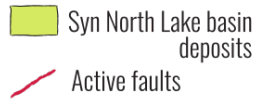

Fig. 10. Scenario for the tectono-sedimentary evolution of the Ekitale Basin. A) Deposition of the Turkana Volcanics Fm ends ca. $28 \mathrm{Ma}$. From B) to D), the Ekitale Basin opens, and the first phase of sedimentation is characterized by the evolution of a river-driven lake. Sedimentation is controlled by alluvial fans from the border faults and rivers that fringe the lake. In E) and F), the second phase of sedimentation is characterized by renewed volcanic activity. Sedimentation is controlled by volcanic centers that triggered repeated pyroclastic deposits, interbedded by fluvial and alluvial sedimentation during volcanic quiescence. G) After $25 \mathrm{Ma}$, border faults no longer accommodate the extension, leading to the abandonment of the basin. A period of tectonic quiescence begins, lasting ca. $10 \mathrm{Ma}$. F) At ca. $14 \mathrm{Ma}$, the North Lake Basin opens and the MRLF truncates the Ekitale Basin. The Ekitale Basin is then inverted. 


\subsection{Chronological constraints}

Based on the available dating (Table 1), several key periods in the history of the Ekitale Basin can be defined. Sedimentation in the Ekitale Basin began after ca. $28 \mathrm{Ma}$ (age of the last lava flows (U0) that predate deposition of the Topernawi Fm). The duration between the deposition of the last lava flows and the first lacustrine (U1) and alluvial fan delta deposits (U2) remains unknown. Yet, at the top of the last lava flows, there is an absence of a pervasive and well-developed paleosol as well as a lack of thin fluvial- or runoff-derived sediment cover. This makes unlikely the possibility of a long exposure prior to the deposition of $\mathrm{U} 1$ and suggests a relatively rapid initiation of deposition in the Ekitale Basin following the emplacement of the Turkana Volcanics Fm. Additionally, the oldest dykes that cross-cut the Topernawi Fm are dated ca. 25 Ma. Therefore, the Topernawi Fm was deposited between ca. 28 and ca. $25 \mathrm{Ma}$, indicating the Ekitale Basin evolved during this time interval. The next important event affecting the Ekitale Basin was activation of the N-S structures (Group 2 faults and dykes) and the opening of the North Lake Basin. The timing of the MRLF activation, which marks the opening of the North Lake Basin, has been recently estimated at ca. 14 Ma based on thermochronology (Boone et al., 2018). This is supported by the age of a N-S-oriented Group 2 dyke dated ca. $14 \mathrm{Ma}$ (Table 1), interpreted as coeval to the development of N-S normal faults at the origin of the initiation of the North Lake Basin. We thus consider the Ekitale Basin to have opened ca. $28 \mathrm{Ma}$ and the sedimentation to have been interrupted ca. $25 \mathrm{Ma}$. We also confirm that the North Lake Basin opened ca. 14 Ma leading to the definitive inversion of the Ekitale Basin.

\subsection{Tectono-sedimentary evolution of the Ekitale Basin}

Combining sedimentary and structural analyses, we can summarize the evolution of the Ekitale Basin from its initiation through to its inversion. Major tectonic events and sedimentary dynamics that impacted the Ekitale Basin are integrated into a coherent view of the basin's evolution (Fig. 10).

After the deposition of the Turkana Volcanics Fm ca. 28 Ma (Fig. 10A), the Ekitale Basin opened due to a first extension phase that reactivated pre-existing $\mathrm{N} 30-50^{\circ}$-oriented basement-inherited structures. This led to the development of a depocenter at the top of the Turkana Volcanics Fm (Fig. 10B). This provided an accommodation space to allow the onset of deposition of the Topernawi Fm. Rapidly, this newly formed depression collected water from several rivers that drained the Turkana Volcanics Fm to form a km-scale lake. In the same time, alluvial fan deltas (U2) developed along the active border faults, fed directly by sediments originating from the destruction of the newly created footwalls (Fig. 10B). In the distal portion of alluvial fan deltas, rivers periodically generated hyperpycnal flows during flood episodes to produce low-density turbidites (U1, Fig. 10B). Progressively, the activity of border faults reached a climax, and the topography reached a maximum (Figs. 10C, D). This increased the production of coarse material from the erosion of the footwall to, in turn, supply alluvial fan deltas (U2). The deltas prograded relatively far toward the central portion of the basin (Fig. 10C). At the same time, a river system was captured in the basin and progressively fed an important turbiditic complex (U3, Fig. 10D). Given the amount and the nature of sediment, this river system appears to 
have represented the axial system of the basin as opposed to the transverse system represented by smaller rivers that fed the alluvial fan. Subsequently, one or several volcanic centers located east of the Ekitale Basin generated a first important pyroclastic pulse (U4, Fig. 10E). Other pyroclastic events followed, and -during periods of inactive volcanism - rivers drained the basin (Fig. 10F). The Ekitale Basin evolved as such until its interruption likely at the end of activity along the border faults with the ceasing of extension, slightly before $25 \mathrm{Ma}$ (Fig. 10G). Intense weathering then progressively affected the area of the Topernawi Fm during an almost 11-Ma-long period characterized by tectonic quiescence and non-deposition (Figs. 10G, H). Around $14 \mathrm{Ma}, \mathrm{N}-\mathrm{S}$ faulting was initiated and segmented the Ekitale Basin (Fig. 10H). From then, the general uplift of the area due to its new position in the rift shoulder of the North Lake Basin led to the inversion of the Ekitale Basin. Currently, the Ekitale Basin overlies the Turkana Volcanics Fm on top of the footwall of the North Lake Basin. East of the MRLF, a portion of the Ekitale Basin is likely buried under several kilometers of syn-rift sediments deposited in the North Lake Basin.

\section{IMPLICATIONS FOR EVOLUTION OF THE EARS IN THE TURKANA DEPRESSION}

Together with the Afar region (Bosworth et al., 2005; Macgregor, 2015), the Turkana Depression is an area of the EARS that has been active since the onset of Cenozoic rifting, from ca. 35 Ma to the present (Macgregor, 2015). The modern configuration of the Turkana Depression is derived from a

long evolution and the Ekitale Basin needs to be incorporated into the regional evolution of the Cenozoic rifting. Here, we discuss the timing of the opening of both the Ekitale and the North Lake basins in relation to the temporal framework of the EARS. Then, the different stages of rift evolution in the northern Turkana Depression are described (Fig. 11), while discussing, in particular, factors controlling the structural evolution of the area.

\subsection{Development of the Ekitale and the North Lake basins within the regional chronological framework}

Investigations of the Ekitale Basin show that formation of this basin was initiated ca. 28 Ma and interrupted ca. 25.5 Ma. The Ekitale Basin represents the oldest evidence of surface rupture associated with the Cenozoic rifting in the northern Turkana Depression. Later, the extension was accommodated by initiation of the North Lake Basin to shape the current morphology of the northern Turkana Depression.

It is currently believed that the initial surface rupture associated with Cenozoic rifting in the northern Turkana Depression occurred ca. 15 Ma (Morley et al., 1999; Vétel and Le Gall, 2006; Macgregor, 2015) in the form of small-scale semi-grabens (e.g., the Lapurr and Murua Rith basins). However, we show that the first extensional phase in the northern Turkana Depression is recorded by the Ekitale Basin, and that this phase occurred between $28 \mathrm{Ma}$ and $25 \mathrm{Ma}$, some $13 \mathrm{Ma}$ earlier than previously shown. 
Interestingly, the timing of this extensional phase matches with the Late Oligocene to Early Miocene rift climax in the Lokichar Basin, southern Turkana Depression, and is associated with the deposition of the Lokhone Shale (Morley et al., 1999; Macgregor, 2015). Previously, the Lokichar Basin was the only basin in the Turkana Depression associated with an Eocene-Oligocene extensional pulse, referred to as EARS 1 (Macgregor, 2015). The Ekitale Basin thus indicates that the extensional phase of EARS 1 also affected the northern Turkana Depression; therefore, the EARS 1 extensional phase influenced a larger area than previously depicted.

A second extensional phase (EARS 2, sensu Macgregor, 2015) is at the origin of most of the basins of the EARS. In the Turkana Depression, the onset of this second pulse was suspected to be diachronous, ranging from Upper Miocene in the southern Turkana Depression to Lower Pliocene in the northern Turkana Depression. In the northern Turkana Depression, this second pulse was thought to have begun between 9 and 4.2 Ma (Morley et al., 1999; Vétel and Le Gall, 2006) in association with the opening of the North Lake Basin. However, we show in this study that the North Lake Basin opened ca. $14 \mathrm{Ma}$, thus 5-10 Ma earlier than previously believed. Additionally, the Chew Bahir Basin (that constitutes the termination of the southern Main Ethiopian Rift, Fig. 1B) opened ca. 20 Ma (Bonini et al., 2005; Pik et al., 2008), while the Southern Kerio Basin (northern termination of the Kenyan Rift Valley) began to form ca. $15 \mathrm{Ma}$ (Torres Acosta et al., 2015). Considering these ages, a regional extensional pulse occurred over a $\sim 6 \mathrm{Ma}$ time interval within the northern Kenyan Rift Valley, the Turkana Depression and the southern Main Ethiopian Rift. This pulse of extension is associated with EARS 2 (Macgregor, 2015), and its diachronicity is thus reduced, as revealed by the opening of most of the N-S basins in southern Ethiopia and northern Kenya during the mid-Miocene.

\subsection{Rifting in the northern Turkana Depression: evolution of the controlling factors}

The morphology of the Ekitale Basin is controlled by tectonic structures oriented broadly along a N50 ${ }^{\circ}$ direction, while more recent rift basins of the Turkana Depression, such as the North Lake Basin, are mainly organized along a N-S direction. The development of the Ekitale Basin thus results from differing extensional conditions. Here, we propose a comprehensive model of the successive rifting phases from the pre-rift period to the modern configuration of the northern Turkana Depression. We discuss the nature of regional stresses that drove the development of the Ekitale Basin and the evolution of later rift basins. 
(A) Doming and magmatism - > $28 \mathrm{Ma}$

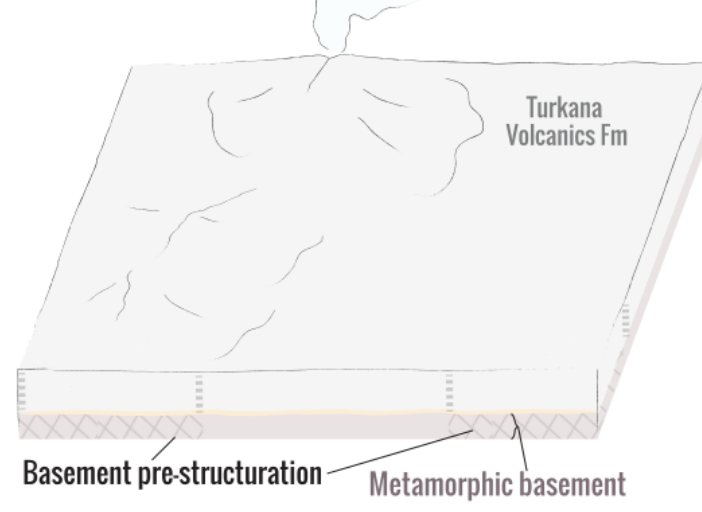

(C) Tectonic quiescence and weathering - 25-14 Ma

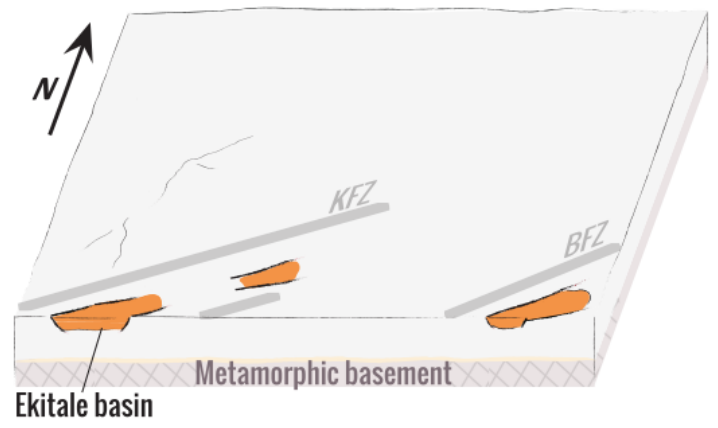

Ekitale basin
(B) EARS 1- Opening of micro-basins - 28-25 Ma

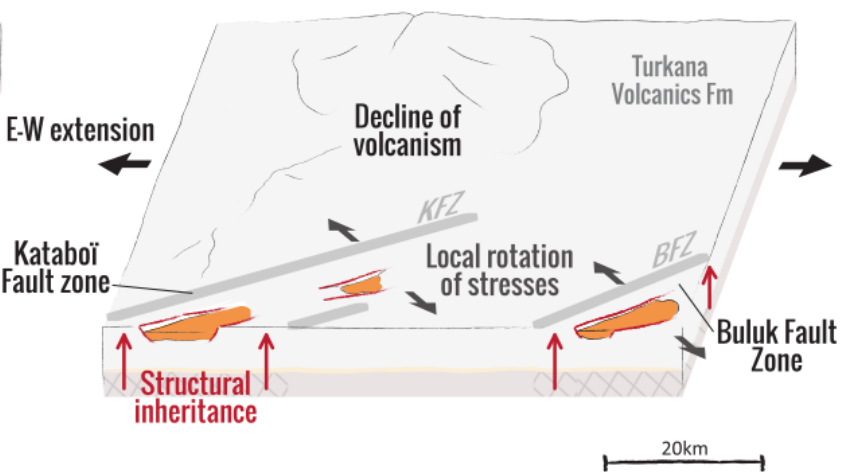

(D) EARS 2 - Opening of the main graben $-<14 \mathrm{Ma}$

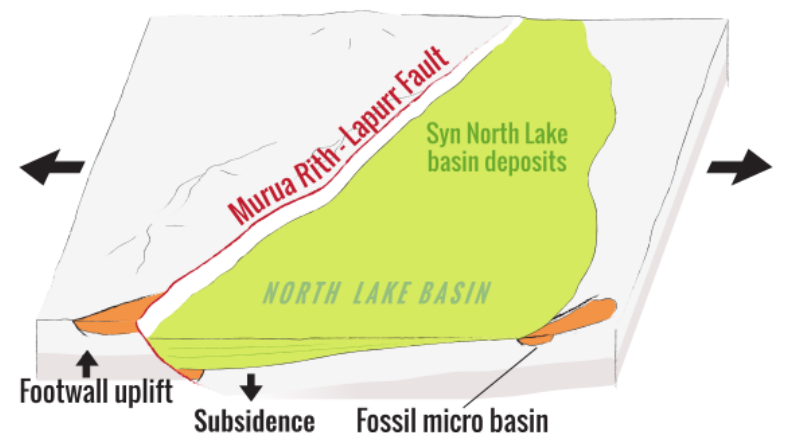

(F) EARS 2 - Inward migration of the deformation $-<0.7 \mathrm{Ma}$

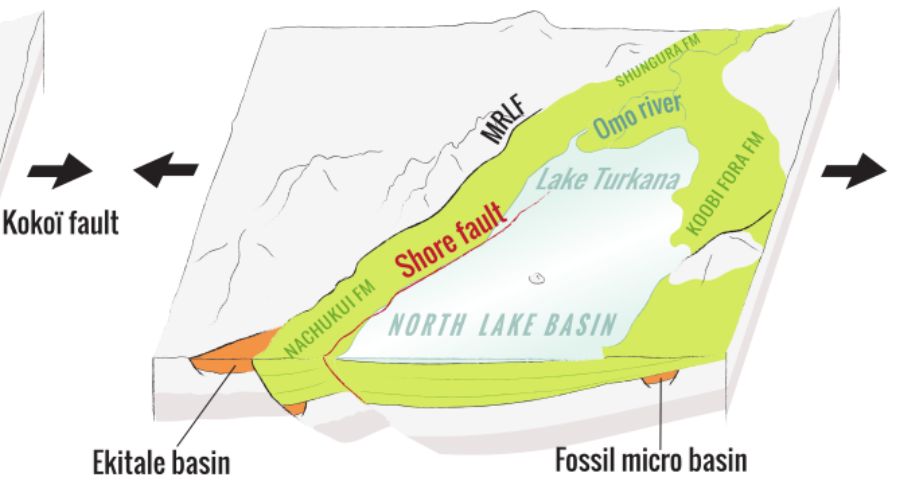

Ekitale basin

(E) EARS 2 - Segmentation of the main graben - $\sim 5 \mathrm{Ma}$

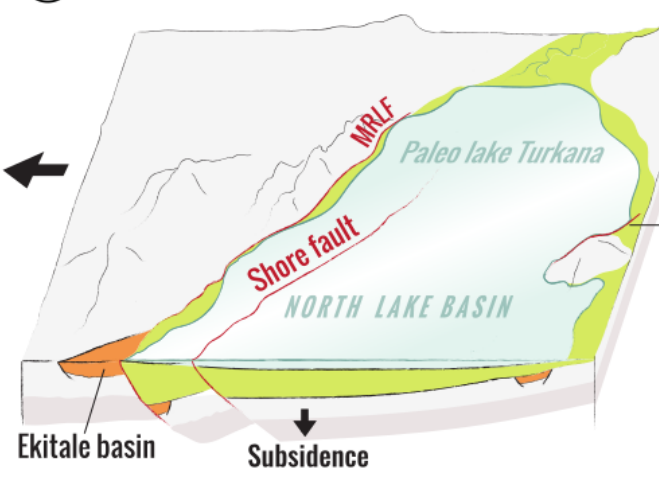

Subsidence

Fig. 11. Scenario for the evolution of the Cenozoic EARS in the northern Turkana Depression. A) Deposition of the extensive Turkana Volcanics Fm until 28 Ma precedes the first surface rupture in the area. B) Early syn-rift micro-basins develop from a low differential stress that favored the reactivation of oblique basement-inherited structures. C) The first episode of rifting ends with a period of tectonic quiescence from ca. 25 to $14 \mathrm{Ma}$. D) An increase of the differential stress and the extension rate lead to the opening of the North Lake Basin and the abandonment of non-optimal faults. E) The main basin rift basin is then segmented into two main depocenters, ca. $5 \mathrm{Ma}$. F) Up to the present-day, the external depocenter has been inverted while deformation has migrated inward to the internal depocenter.

Prior to $28 \mathrm{Ma}$, the area was affected by the deposition of the Turkana Volcanics Fm (Fig. 11A). This volcanism resulted from the intense Late Eocene to mid-Miocene fissural volcanism activity (Walsh 
and Dodson, 1969; Bellieni et al., 1981; Zanettin et al., 1983; Bellieni et al., 1987). After 28 Ma, the EARS 1 pulse reactivated the basement-inherited NE-SW-oriented faults and led to the opening of the Ekitale Basin and other suspected comparable basins (Fig. 11B). Reactivated faults were oriented $\mathrm{N} 30^{\circ}-50^{\circ}$ and thus along a non-optimal direction regarding the E-W-oriented extension estimated at that time (Morley et al., 1999; Vétel and Le Gall, 2006). The opening of basins comparable to the Ekitale Basin, referred to as micro-basins, thus results from oblique rifting along the NW-SE direction. In addition, the reactivation of non-optimal faults requires less differential stress than those required to initiate failure of an intact and isotropic rock (Morley et al. 2004). This suggests that the oblique opening of the Ekitale Basin reflects a period during which both differential stress and the amount of extension were low. Thus, the initiation and morphology of the micro-basins are suspected to have been mainly driven by the ability of pre-existing inherited structures to be reactivated, while the opening of new structures was prevented by insufficient extension. The opening of these microbasins contrasts with usual rift evolution models in which early syn-rift basins evolve within similar stress environments having a similar orientation (Gawthorpe and Leeder, 2000). This newly described type of syn-rift basin may develop during long-term rift evolution, separating pre-rift periods that experience no stress and the rift climax during which both differential stress and the amount of extension are high. Micro-basins comparable to the Ekitale Basin may be favored during early-rift periods and may thus be characteristic of typical early-rift systems.

Following a period of tectonic quiescence between ca. 25 and ca. 14 Ma (Fig. 11C), the EARS 2 extensional pulse opened the North Lake Basin in the northern Turkana Depression (Fig. 11D). Estimated at ca. $14 \mathrm{Ma}$, the MRLF and other N-S-oriented structures, such as the minor faults and dykes, were initiated (Fig. 11D). They then truncated the Turkana Volcanics Fm and the Ekitale Basin. The remnant portion of the Ekitale Basin located on the newly formed rift shoulder was uplifted, leading to its inversion and abandonment. The newly formed North Lake Basin depocenter was controlled mainly by the activity of the MRLF. During this second extensional phase, previously active non-optimal $\mathrm{N} 30^{\circ}-50^{\circ}$ faults were abandoned and optimal N-S-oriented faults developed. This transition from oblique to orthogonal rifting reflects the expression of a marked increase of $\sigma 1$, and thus an increase of the differential stress that focused the rupture along $\sigma 2$ (Morley et al., 2004). Thus, the amount of extension is believed to have been much greater during EARS 2 than during EARS 1 in the northern Turkana Depression.

After the opening of the North Lake Basin, several minor faults developed in the basin, parallel to the MRLF. One of them, the shore fault (Nutz et al., 2017), started to accommodate an important extension to finally segment the North Lake Basin into an external and an internal sub-basin (Fig. $11 \mathrm{E})$. Although the timing of the segmentation remains unknown, seismic lines display wedging associated with the shore fault at least since 4.2-5 Ma, directly after the deposition of the Pliocene volcanics (Africa Oil, 2016). Very soon after, the shore fault became dominant in accommodating the extension. Around 0.7 Ma, the MRLF was interrupted (Nutz et al., 2017). From this point, the main 
depocenter was associated with the shore fault while the external sub-basin was inverted (Fig. 11F). This evolution marks the inward migration of the border fault resulting from the incapacity of the MRLF to continue to accommodate any extension. Inward migration is usually attributed to an increase in the amount of extension (Corti et al., 2010, 2013).

Finally, the proposed rift evolution in the northern Turkana Depression was mainly driven by a progressive transition from a low to high regional differential stress and by a progressive increase in the amount of extension over time. Evolutionary phases were interrupted by periods of tectonic quiescence. However, evolution of differential stress and the amount of extension are suspected to evolve in a broadly similar manner for most rift systems, and thus their combined evolution may be shared by other rift basins. The identification of similar micro-basins related to an early-rift period in other rift systems could have wider implications, altering previously depicted timings of rift initiation and rifting history.

\section{CONCLUSION}

Sedimentology and structures of the Ekitale Basin are documented through the detailed geological mapping, interpretation of five basin-scale sections and sedimentary facies analysis. The Ekitale Basin consists of a $\mathrm{km}$-scale graben bounded by $\mathrm{N} 30^{\circ}-50^{\circ}$-oriented normal faults. These normal faults originate from the reactivation, slightly after $28 \mathrm{Ma}$, of pre-existing basement-inherited structures. The sedimentary infill of the basin is referred to as the Topernawi Fm. From its base to top, it is composed of alluvial fan deltas and turbiditic complexes deposited in a lacustrine setting that are overlain by repeating pyroclastic deposits-when sedimentation was controlled by volcanic activity. The pyroclastic deposits are interbedded by fluvial deposits laid down during periods of volcanic quiescence. Finally, the evolution of the Ekitale Basin ceased ca. $25 \mathrm{Ma}$, likely due to the interruption of sufficient stress to maintain the extension. Later, concomitant with the development of the North Lake Basin at ca. $14 \mathrm{Ma}, \mathrm{N}-\mathrm{S}$-oriented faults and dykes segmented the Ekitale Basin and led to its abandonment and inversion. The Ekitale Basin is interpreted as a syn-rift basin associated with the first pulse of extension attributed to the Cenozoic rifting (EARS 1 sensu Macgregor, 2015). The Ekitale Basin characterizes the oldest expression of the surface rupture associated with the Cenozoic rifting in the northern Turkana Depression. The opening of the Ekitale Basin originated from both a low amount of extension and a low differential stress that favored the reactivation of non-optimal inherited faults during the early stages of Cenozoic rifting.

In the northern Turkana Depression, the Cenozoic rifting evolved through four main phases. Between 28 and $25 \mathrm{Ma}$, a first extensional pulse (EARS 1) was characterized by the development of non-optimal (regarding the E-W-oriented extension at that time) syn-rift basins, as the reactivation of pre-existing structures was the dominant control on basin morphology. Between 25 and $14 \mathrm{Ma}$, a relative tectonic

quiescence led to the development of a significant weathering profile. From $14 \mathrm{Ma}$, a second 
extensional pulse (EARS 2) produced a large N-S-oriented half-graben referred to as the North Lake Basin. It is attributed to the onset of the rift climax. The transition from oblique (EARS 1) to orthogonal (EARS 2) rifting is interpreted to reflect both a higher differential stress and a greater amount of extension. Finally, the North Lake Basin was segmented into two sub-basins prior to 4.2 $\mathrm{Ma}$, while the internal sub-basin became the only active depocenter after $0.7 \mathrm{Ma}$.

We present the first detailed evolution of the Cenozoic rifting in the northern Turkana Depression from the pre-rift settings to the modern configuration, refining the mode and timing of EARS 1 and EARS 2 phases in the area. A new type of syn-rift basin is also documented, characterizing periods of low extension during early or calm phases of continental rifting. The identification of Ekitale-like synrift basins in other continental rift systems is the next step. Finally, this field-based investigation provides valuable new results for elaborating and the refining continental rift models.

\section{ACKNOWLEDGMENTS}

This work was made possible thanks to a research grant from Total (Rift Lake Sedimentology - RiLakS project; PI: MS) that provided post-doctoral funding to AN and a Master grant to TR. We warmly thank Sonia Harmand-Lewis, Jason Lewis and Sandrine Prat for sharing their remarkable camp facilities at Topernawi Laga, as well as all the members of the West Turkana Archeological Project. Satellite imagery (SPOT) was acquired at a special rate thanks to CNES/ISIS/Theia-Geosud. This work was conducted under a research permit attributed by NACOSTI. National Oil Corporation of Kenya (NOCK) is warmly thanked for their partnership (S. Hassan-Athmani, K. Nyagah, G. Muia, A. Karanja, A. Ofafa). We are extremely grateful to our guides, Francis Emekwi Ekai and Sammy Lokorodi from Nariokotome. We thank Jackson Dongol for field assistance, and James Ekitale for outstanding camp facilities. We thank the French Embassy in Kenya for help and support. J.-J. Tiercelin, M. Lescanne, M. Bez, and M. Diraison are warmly thanked for fruitful discussions. We thank Marco Patacci, Xin Shan and an anonymous reviewer for their constructive comments that helped improve the manuscript. We finally thank Murray Hay (Maxafeau Editing Services) for editing the English of the original manuscript. 


\section{REFERENCES}

Abdelfettah, Y., Tiercelin, J.-J., Tarits, P., Hautot, S., Maia, M., and Thuo, P. (2016). Subsurface structure and stratigraphy of the northwest end of the Turkana Basin, Northern Kenya Rift, as revealed by magnetotellurics and gravity joint inversion. Journal of African Earth Sciences, 119(Supplement C), 120-138.

Ackermann, R. V., Schlische, R. W., and Withjack, M. O. (2001). The geometric and statistical evolution of normal fault systems: an experimental study of the effects of mechanical layer thickness on scaling laws. Journal of Structural Geology, 23(11), 1803-1819.

Africa Oil Reports (2016). Corporate presentations. Last retrieve May 4, 2017, from

http://www.africaoilcorp.com/s/presentations.asp

Alexander, J., Bridge, J., Cheel, R., and Leclair, S. (2001). Bedforms and associated sedimentary structures formed under supercritical water flows over aggrading sand beds. Sedimentology, 48(1), 133-152.

Arambourg, C., and Wolff, R. (1969). Nouvelles données paléontologiques sur l'age des gès du Lubur (Turkana grits) à l'Ouest du lac Rodolphe. Comptes Rendus Société Géologique de France, 6(1), 190-202.

Ashley, G. M., Southard, J. B., and Boothroyd, J. C. (1982). Deposition of climbing-ripple beds: a flume simulation. Sedimentology, 29(1), 67-79.

Bellieni, G., Visentin, E. J., Piccirillo, E., and Zanettin, B. (1987). Volcanic cycles and magmatic evolution in northern Turkana (Kenya). Tectonophysics, 143(1), 161168.

Bellieni, G., Visentin, E. J., Zanettin, B., Piccirillo, E., Di Brozolo, F. R., and Rita, F. (1981). Oligocene transitional tholeiitic magmatism in northern Turkana (Kenya): comparison with the coeval Ethiopian volcanism. Bulletin Volcanologique, 44(3), 411-427.

Bonini, M., Corti, G., Innocenti, F., Manetti, P., Mazzarini, F., Abebe, T., and Pecskay, Z. (2005). Evolution of the Main Ethiopian Rift in the frame of Afar and Kenya rifts propagation. Tectonics, 24(1), TC1007.

Boone, S. C., Seiler, C., Kohn, B. P., Gleadow, A. J. W., Foster, D. A., and Chung, L. (2018). Influence of rift superposition on lithospheric response to East African Riftsystem extension: Lapur Range, Turkana, Kenya. Tectonics, 37(1), 2017 TC004575.

Boschetto, H., Brown, F., and McDougall, I. (1992). Stratigraphy of the Lothidok Range, northern Kenya, and
$\mathrm{K} / \mathrm{Ar}$ ages of its Miocene primates. Journal of Human Evolution, 22(1), 47-71.

Bosworth, W., Huchon, P., and McClay, K. (2005). The Red Sea and Gulf of Aden Basins. Journal of African Earth Sciences, 43(1), 334-378.

Brown, F., and Feibel, C. (1991). Stratigraphy, depositional environments and palaeogeography of the Koobi Fora Formation. In (J. M. Harris, Ed.) Koobi Fora Research Project, vol.3, The fossil ungulates: geology, fossil artiodactyls, and palaeoenvironments (pp. 1-30). Clarendon Press Oxford.

Brown, F. H., and Fuller, C. R. (2008). Stratigraphy and tephra of the Kibish Formation, southwestern Ethiopia. Journal of Human Evolution, 55(3), 366-403.

Bruhn, R. L., Brown, F. H., Gathogo, P. N., and Haileab, B. (2011). Pliocene volcano-tectonics and paleogeography of the Turkana Basin, Kenya and Ethiopia. Journal of African Earth Sciences, 59(2), 295-312.

Brune, S., Corti, G., and Ranalli, G. (2017). Controls of inherited lithospheric heterogeneity on rift linkage: Numerical and analog models of interaction between the Kenyan and Ethiopian rifts across the Turkana depression. Tectonics, 36(9), 2017 TC004739.

Buck, W. R. (1991). Modes of continental lithospheric extension. Journal of Geophysical Research: Solid Earth, 96(B12), 20161-20178.

Butzer, K. W., and Thurber, D. L. (1969). Some Late Cenozoic sedimentary formations of the Lower Omo Basin. Nature, 222(5199), 1132-1143.

Cartwright, J. A., Trudgill, B. D., and Mansfield, C. S. (1995). Fault growth by segment linkage: an explanation for scatter in maximum displacement and trace length data from the Canyonlands Grabens of SE Utah. Journal of Structural Geology, 17(9), 1319-1326.

Cas R., and Wright J. (1988). Volcanic Successions Modern and Ancient: A geological approach to processes, products and successions. Springer Netherlands, $528 \mathrm{p}$.

Chorowicz, J. (2005). The east African rift system. Journal of African Earth Sciences, 43(1), 379-410.

Cole, P. D. (1991). Migration direction of sand-wave structures in pyroclastic-surge deposits: Implications for depositional processes. Geology, 19(11), 1108-1111. 
Corti, G., Ranalli, G., Agostini, A., and Sokoutis, D. (2013). Inward migration of faulting during continental rifting: Effects of pre-existing lithospheric structure and extension rate. Tectonophysics, 594(Supplement C), 137-148.

Corti, G., Ranalli, G., Mulugeta, G., Agostini, A., Sani, F., and Zugu, A. (2010). Control of the rheological structure of the lithosphere on the inward migration of tectonic activity during continental rifting. Tectonophysics, 490(3), 165-172.

Cowie, P. A. (1998). A healing-reloading feedback control on the growth rate of seismogenic faults. Journal of Structural Geology, 20(8), 1075-1087.

Cowie, P. A., Gupta, S., and Dawers, N. H. (2000). Implications of fault array evolution for synrift depocentre development: insights from a numerical fault growth model. Basin Research, 12(3-4), 241-261.

de Heinzelin, J. (1983). The Omo Group: Tervuren, Belgique, Musée Royal de l'Afrique Central, Annales, Série in $8^{\circ}$ Sciences Géologiques, 85, 241-303.

Dawers, N. H., and Anders, M. H. (1995). Displacementlength scaling and fault linkage. Journal of Structural Geology, 17(5), 607-614.

Ducrocq, S., Boisserie, J. R., Tiercelin, J. J., Delmer, C., Garcia, G., Kyalo, M. F., Leakey, M. G., Marivaux, L., Otero, O., Peigné, S., Tassy, P and Lihoreau, F. (2010). New Oligocene vertebrate localities from Northern Kenya (Turkana basin). Journal of Vertebrate Paleontology, 30(1), 293-299.

Duller, R. A., Mountney, N. P., Russell, A. J., and Cassidy, N. C. (2008). Architectural analysis of a volcaniclastic jökulhlaup deposit, southern Iceland: sedimentary evidence for supercritical flow. Sedimentology, 55(4), 939-964.

Dunkelman, T. J., Karson, J. A., and Rosendahl, B. R. (1988). Structural style of the Turkana rift, Kenya. Geology, 16(3), 258-261.

Dunkelman, T. J., Rosendahl, B. R., and Karson, J. A. (1989). Structure and stratigraphy of the Turkana rift from seismic reflection data. Journal of African Earth Sciences (and the Middle East), 8(2), 489-510.

Ebinger, C. J., and Sleep, N. H. (1998). Cenozoic magmatism throughout East Africa resulting from impact of a single plume. Nature, 395(6704), 788-791.

Ebinger, C. J., Yemane, T., Harding, D. J., Tesfaye, S., Kelley, S., and Rex, D. C. (2000). Rift deflection, migration, and propagation: Linkage of the Ethiopian and Eastern rifts, Africa. Geological Society of America Bulletin, 112(2), 163-176.

Feibel, C. S. (2003). Stratigraphy and depositional history of the Lothagam sequence. In M. G. Leakey and J. M. Harris (eds.), Lothagam: The Dawn of Humanity in Eastern Africa, by M. G. Leakey and J. M. Harris (pp. 1729). Columbia University Press, New York.

Feibel, C. S. (2011). A geological history of the Turkana Basin. Evolutionary Anthropology: Issues, News, and Reviews, 20(6), 206-216.

Fielding, C. R. (2006). Upper flow regime sheets, lenses and scour fills: extending the range of architectural elements for fluvial sediment bodies. Sedimentary Geology, 190(1), 227-240.

Fisher, R. V. (1961). Proposed classification of volcaniclastic sediments and rocks. Geological Society of America Bulletin, 72(9), 1409-1414.

Fisher, R. V., and Schmincke, H. U. (1984). Pyroclastic Rocks, Springer, Berlin, 472 pp.

Fossen, H., and Rotevatn, A. (2016). Fault linkage and relay structures in extensional settings-A review. EarthSciences Reviews, 154, 14-28.

Furman, T., Bryce, J. G., Karson, J., and lotti, A. (2004). East African Rift System (EARS) Plume Structure: Insights from Quaternary Mafic Lavas of Turkana, Kenya. Journal of Petrology, 45(5), 1069-1088.

Furman, T., Kaleta, K. M., Bryce, J. G., and Hanan, B. B. (2006). Tertiary mafic lavas of Turkana, Kenya: constraints on East African plume structure and the occurrence of high- $\mu$ volcanism in Africa. Journal of Petrology, 47(6), 1221-1244.

Gathogo, P. N., and Brown, F. H. (2006). Stratigraphy of the Koobi Fora Formation (Pliocene and Pleistocene) in the lleret region of northern Kenya. Journal of African Earth Sciences, 45(4), 369-390.

Gathogo, P. N., Brown, F. H., and McDougall, I. (2008). Stratigraphy of the Koobi Fora Formation (Pliocene and Pleistocene) in the Loiyangalani region of northern Kenya. Journal of African Earth Sciences, 51(5), 277-297.

Gawthorpe, R., and Leeder, M. (2000). Tectonosedimentary evolution of active extensional basins. Basin Research, 12(3-4), 195-218.

Gilbert, J. S., and Lane, S. J. (1994). The origin of accretionary lapilli. Bulletin of Volcanology, 56(5), 398411. 
Gregory, J. W. (1896). The Great Rift Valley: being the narrative of a journey to Mount Kenya and Lake Baringo: with some account of the geology, natural history, anthropology and future prospects of British East Africa. John Murray, London, United Kingdom, pp. 422.

Gupta, S., Cowie, P. A., Dawers, N. H., and Underhill, J. R. (1998). A mechanism to explain rift-basin subsidence and stratigraphic patterns through fault-array evolution. Geology, 26(7), 595-598.

Harris, J. M., Leakey, M. G., and Brown, F. H. (1988). Stratigraphy and paleontology of Pliocene and Pleistocene localities west of Lake Turkana, Kenya. Natural History Museum of Los Angeles County.

Hart, B. S., and Plint, A. G. (1995). Gravelly Shoreface and Beachface Deposits. In A. G. Plint (Ed.), Sedimentary Facies Analysis (pp. 75-99). Blackwell Publishing Ltd., Hoboken, NJ.

Hendrie, D., Kusznir, N., Morley, C., and Ebinger, C. (1994). Cenozoic extension in northern Kenya: a quantitative model of rift basin development in the Turkana region. Tectonophysics, 236(1), 409-438.

Jicha, B. R., and Brown, F. H. (2014). An age for the Korath Range, Ethiopia and the viability of $40 \mathrm{Ar} / 39 \mathrm{Ar}$ dating of kaersutite in Late Pleistocene volcanics. Quaternary Geochronology, 21, 53-57.

Jobe, Z. R., Lowe, D. R., and Morris, W. R. (2012). Climbing-ripple successions in turbidite systems: depositional environments, sedimentation rates and accumulation times. Sedimentology, 59(3), 867-898.

Kneller, B. (2003). The influence of flow parameters on turbidite slope channel architecture. Marine and Petroleum Geology, 20(6-8), 901-910.

Macdonald, G. A. (1953). Pahoehoe, aa, and block lava. American Journal of Science, 251(3), 169-191.

Macgregor, D. (2015). History of the development of the East African Rift System: A series of interpreted maps through time. Journal of African Earth Sciences, 101, 232-252.

Mansfield, C., and Cartwright, J. (2001). Fault growth by linkage: observations and implications from ana

Mulder, T., Syvitski, J. P. M., Migeon, S., Faugères, J.-C., and Savoye, B. (2003). Marine hyperpycnal flows: initiation, behavior and related deposits. A review. Marine and Petroleum Geology, 20(6), 861-882.

Mutti, E., Tinterri, R., Benevelli, G., Biase, D. di, and Cavanna, G. (2003). Deltaic, mixed and turbidite sedimentation of ancient foreland basins. Marine and Petroleum Geology, 20(6-8), 733-755.

Nutz, A., Schuster, M., Boës, X., and Rubino, J.-L. (2017). Orbitally-driven evolution of Lake Turkana (Turkana Depression, Kenya, EARS) between 1.95 and $1.72 \mathrm{Ma:A}$ sequence stratigraphy perspective. Journal of African Earth Sciences, 125, 230-243.

Nutz, A., Schuster, M., Ghienne, J.-F., Roquin, C., and Bouchette, F. (2016). Wind-driven waterbodies: a new category of lake within an alternative sedimentologically-based lake classification. Journal of Paleolimnology, 59(2), 1-11.

Owen, G. (1996). Experimental soft-sediment deformation: structures formed by the liquefaction of unconsolidated sands and some ancient examples. Sedimentology, 43(2), 279-293.

Owen, G., and Moretti, M. (2011). Identifying triggers for liquefaction-induced soft-sediment deformation in sands. Sedimentary Geology, 235(3), 141-147.

Owen R. B., Barthelme J. W., Renaut R. W. Vincens A. (1982). Palaeolimnology and archaeology of Holocene deposits north-east of Lake Turkana, Kenya. Nature, 298, 523-529

Pettijohn, F. J., Potter, P. E., and Siever, R. (2012). Sand and Sandstone. New York, Springer-Verlag, 553 p.

Pik, R., Marty, B., Carignan, J., Yirgu, G., and Ayalew, T. (2008). Timing of East African Rift development in southern Ethiopia: Implication for mantle plume activity and evolution of topography. Geology, 36(2), 167-170.

Postma, G. (1990). Depositional architecture and facies of river and fan deltas: a synthesis. In Colella, A. and Prior D.B., eds., Coarse-Grained Deltas: International Association of Sedimentologists Special Publication, 10, 13-27.

Prosser, S. (1993). Rift-related linked depositional systems and their seismic expression. Geological Society, London, Special Publications, 71(1), 35-66.

Renne, P. R., Mundil, R., Balco, G., Min, K., and Ludwig, K. R. (2010). Joint determination of $40 \mathrm{~K}$ decay constants and $40 \mathrm{Ar} * / 40 \mathrm{~K}$ for the Fish Canyon sanidine standard, and improved accuracy for $40 \mathrm{Ar} / 39 \mathrm{Ar}$ geochronology. Geochimica et Cosmochimica Acta, 74(18), 5349-5367.

Renne, P. R., Swisher, C. C., Deino, A. L., Karner, D. B., Owens, T. L., and DePaolo, D. J. (1998). Intercalibration of standards, absolute ages and uncertainties in 40Ar/39Ar dating. Chemical Geology, 145(1), 117-152. 
Rooney, T. O., Herzberg, C., and Bastow, I. D. (2012). Elevated mantle temperature beneath East Africa. Geology, 40(1), 27-30.

Rosendahl, B. R. (1987). Architecture of continental rifts with special reference to East Africa. Annual Review of Earth and Planetary Sciences, 15, 445-503.

Ruffet, G., Féraud, G., and Amouric, M. (1991).

Comparison of 40Ar-39Ar conventional and laser dating of biotites from the North Trégor Batholith. Geochimica et Cosmochimica Acta, 55(6), 1675-1688.

Ruffet, G., Féraud, G., Balèvre, M., and Kiénast, J.-R. (1995). Plateau ages and excess argon in phengites: an 40Ar/39Ar laser probe study of Alpine micas (Sesia Zone, Western Alps, northern Italy). Chemical Geology, 121(1), 327-343.

Schmincke, H.-U., Fisher, R. V., and Waters, A. C. (1973). Antidune and chute and pool structures in the base surge deposits of the Laacher See area, Germany. Sedimentology, 20(4), 553-574.

Simon, B., Guillocheau, F., Robin, C., Dauteuil, O., Nalpas, T., Pickford, M., Senut, B., Lays, P., Bourges, P., $B e z$, M. (2017). Deformation and sedimentary evolution of the Lake Albert Rift (Uganda, East African Rift System). Marine and Petroleum Geology, 86(Supplement C), 1737.

Smith, R. L. (1960). Ash Flows. Geological Society of America Bulletin, 71(6), 795-841.

Talling, P. J., Masson, D. G., Sumner, E. J., and Malgesini, G. (2012). Subaqueous sediment density flows: Depositional processes and deposit types. Sedimentology, 59(7), 1937-2003.

Tiercelin, J.-J., and Lezzar, K.-E. (2002). A 300 Million Years History of Rift Lakes in Central and East Africa: An Updated Broad Review. In E. O. Odada and D. O. Olago (Eds.), The East African Great Lakes: Limnology, Palaeolimnology and Biodiversity (pp. 3-60). Springer Netherlands.

Tiercelin, J.-J., Potdevin, J.-L., Morley, C., Talbot, M., Bellon, H., Rio, A., Le Gall, B.,Vétel, W. (2004).

Hydrocarbon potential of the Meso-Cenozoic Turkana Depression, northern Kenya. I. Reservoirs: depositional environments, diagenetic characteristics, and source rock-reservoir relationships. Marine and Petroleum Geology, 21(1), 41-62.

Tiercelin, J.-J., Schuster, M., Roche, H., Brugal, J.-P., Thuo, P., Prat, S., Haramand, S., Davtian, G., Barrat, J.-A., Bohn, M. (2010). New considerations on the stratigraphy and environmental context of the oldest (2.34 Ma)
Lokalalei archaeological site complex of the Nachukui Formation, West Turkana, northern Kenya Rift. Journal of African Earth Sciences, 58(2), 157-184.

Tiercelin, J.-J., Potdevin, J.-L., Thuo, P. K., Abdelfettah, Y., Schuster, M., Bourquin, S., Bellon, H., Clément, J.-P., Guillou, H., Nalpas, T., Ruffet, G. (2012a). Stratigraphy, sedimentology and diagenetic evolution of the Lapur Sandstone in northern Kenya: Implications for oil exploration of the Meso-Cenozoic Turkana depression. Journal of African Earth Sciences, 71-72(Supplement C), 43-79.

Tiercelin, J.-J., Thuo P.K., Potdevin J.-L., Nalpas T. (2012b). Hydrocarbon Prospectivity in Mesozoic and Early - Middle Cenozoic Rift Basins of Central and Northern Kenya, Eastern Africa, in D. Gao, ed., Tectonics and sedimentation: Implications for petroleum systems: American Association of Petroleum Geologists Memoir 100, p. 179-207.

Torres Acosta, V., Bande, A., Sobel, E. R., Parra, M., Schildgen, T. F., Stuart, F., and Strecker, M. R. (2015). Cenozoic extension in the Kenya Rift from lowtemperature thermochronology: Links to diachronous spatiotemporal evolution of rifting in East Africa. Tectonics, 34(12), $2015 T C 003949$.

Vétel, W. (2005). Dynamique de l'extension intracontinentale en contexte de rift magmatique: le Rift Turkana (Nord Kenya) de l'Eocène à l'Actuel. Ph.D. Thesis, Université de Bretagne occidentale-Brest. Retrieved from http://tel.archives-ouvertes.fr/tel00009294/.

Vétel, W., and Le Gall, B. (2006). Dynamics of prolonged continental extension in magmatic rifts: the Turkana Rift case study (North Kenya). Geological Society, London, Special Publications, 259(1), 209-233.

Walker, G. P. (1984). Characteristics of dune-bedded pyroclastic surge bedsets. Journal of Volcanology and Geothermal Research, 20(3), 281-296.

Walsh, J., and Dodson, R. G. (1969). Geology of Northern Turkana. Geological Survey of Kenya.

Waters, A. C., and Fisher, R. V. (1971). Base surges and their deposits: Capelinhos and Taal volcanoes. Journal of Geophysical Research, 76(23), 5596-5614.

Wescott, W., Morley, C., and Karanja, F. (1993). Geology of the Turkana Grits in the Lariu range and Mt. Porr areas, southern Lake Turkana, northwestern Kenya. Journal of African Earth Sciences (and the Middle East), 16(4), 425-435. 
Whipp, P. S., Jackson, C. L., Schlische, R. W., Withjack, M. O., and Gawthorpe, R. L. (2016). Spatial distribution and evolution of fault-segment boundary types in rift systems: observations from experimental clay models. Geological Society, London, Special Publications, 439(1), 79-107.

Williamson, P. G., and Savage, R. J. (1986). Early rift sedimentation in the Turkana basin, northern Kenya. Geological Society, London, Special Publications, 25(1), 267-283.

Wilson, C. J. N., and Walker, G. P. L. (1982). Ignimbrite depositional facies: the anatomy of a pyroclastic flow. Journal of the Geological Society, 139(5), 581-592.

Wohletz, K. H., and Sheridan, M. F. (1979). A model of pyroclastic surge. Geological Society of America Special Papers, 180, 177-194.

Wright, L. D. (1977). Sediment transport and deposition at river mouths: A synthesis. Geological Society of America Bulletin, 88(6), 857-868.
Zanettin, B., Justin Visentin, E., Bellieni, G., Piccirillo, E., and Rita, F. (1983). Le volcanisme du Bassin du NordTurkana (Kenya): Age, succession et évolution structurale. Rifts et Fossés Anciens. Bulletin Des Centres de Recherches Exploration-Production Elf-Aquitaine, 7, 249-255.

Zavala, C., Arcuri, M., Meglio, M. D., Diaz, H. G., and Contreras, C. (2011). A Genetic Facies Tract for the Analysis of Sustained Hyperpycnal Flow Deposits. In R. M. Slatt and C. Zavala, eds., Sediment transfer from shelf to deep water-Revisiting the delivery system (pp. 3151). American Association of Petroleum Geologists Studies in Geology No. 61.

Zavala, C., Arcuri, M., and Valiente, L. (2012). The importance of plant remains as diagnostic criteria for the recognition of ancient hyperpycnites. Revue de Paléobiologie, 11, 457-469.logue models. Journal of Structural Geology, 23(5), 745-763. 